Article

\title{
Forms of Nitrogen and Phosphorus in Suspended Solids: A Case Study of Lihu Lake, China
}

\author{
Jialu Li ${ }^{1,2}$ and Qiting Zuo ${ }^{1,2, *}$ \\ 1 School of Water Conservancy Engineering, Zhengzhou University, Zhengzhou 450001, China; \\ jialuli1227@163.com \\ 2 Zhengzhou Key Laboratory of Water Resource and Water Environment, Zhengzhou 450001, China \\ * Correspondence: zuoqt@zzu.edu.cn; Tel.: +86-136-5381-7257
}

Received: 9 April 2020; Accepted: 4 June 2020; Published: 19 June 2020

\begin{abstract}
Suspended solids are an important part of lake ecosystems, and their nitrogen and phosphorus contents have a significant effect on water quality. However, information on nitrogen and phosphorus forms in suspended solids remains limited. Therefore, a case study was conducted in Lihu Lake (China), a lake with characteristically high amounts of suspended solids. Nitrogen and phosphorus speciation in suspended solids was analyzed through a sequential extraction method. We also evaluated the sources of various forms of nitrogen and phosphorus and their different effects on eutrophication. The total nitrogen (TN) content was 758.9-3098.1 mg/kg. Moreover, the proportions of various $\mathrm{N}$ forms in the suspended solids of the study areas were ranked as follows: Hydrolyzable nitrogen $(\mathrm{HN})>$ residual nitrogen $(\mathrm{RN})>$ exchangeable nitrogen $(\mathrm{EN})$. Total phosphorus (TP) ranged from 294.8 to $1066.4 \mathrm{mg} / \mathrm{kg}$, and $58.6 \%$ of this TP was inorganic phosphorus (IP). In turn, calcium (Ca)-bound inorganic phosphorus (Ca-Pi) was the main component of IP. The correlation between various nitrogen and phosphorus forms showed that there were different sources of suspended nitrogen and phosphorus throughout Lihu Lake. Correlation analysis of water quality indices and comparative analysis with surface sediments showed that in Lihu Lake, the dissolved nitrogen and phosphorus contents in water were influenced by sediment through diffusion, while particle phosphorus content in water was influenced by suspended solids through adsorption; however, due to the higher phosphorus contents in suspended solids, we should pay more attention to the impact of suspended solids.
\end{abstract}

Keywords: suspended solids; nitrogen; phosphorus; form analysis; Lihu Lake

\section{Introduction}

Eutrophication is among the most important threats to global surface water quality. Currently, more than $75 \%$ of closed water bodies worldwide present some degree of eutrophication [1-3]. According to the Organization for Economic Cooperation and Development (OECD), "eutrophication" is defined as an undesirable degradation in water quality associated with increases in the productivity of algae and aquatic plants, which is caused by increases in nutrient concentrations and affects the beneficial uses of water. As socioeconomic development continues to grow, the term "eutrophication" is commonly used to refer to events linked to anthropogenic activities, typically within a short time scale (i.e., hours, days, months, years) [4,5]. Eutrophication can cause great damage to aquatic ecosystems and has adverse effects on aquatic products, water services, human health, and economic activities in surrounding areas [6-8]. The mechanisms of eutrophic formation and diffusion have been studied since the 1970s. Nitrogen (N) and phosphorus (P) are the main growth-limiting nutrients for algae, bacteria, protozoa, and other aquatic organisms that inhabit freshwater ecosystems [9-11]. However, the excessive input of these nutrients may accelerate the eutrophication process in the affected water 
bodies. Therefore, the effects of nitrogen and phosphorus on eutrophication have been studied both in water and sediments.

Although external inputs are the main factor leading to the eutrophication of lakes, the biochemical reaction of nitrogen and phosphorus at the sediment/suspended solid water interface has an impact on the nutrient contents in water. Different forms of nitrogen and phosphorus play different roles in biogeochemical cycles and, therefore, contribute differently to eutrophication [12,13]. In general, nitrogen and phosphorus are converted into different molecular forms at the sediment/suspended solid water interface. Nitrogen in sediments and suspended solids can be divided into convertible and non-convertible forms. Among them, convertible nitrogen participates actively in the nitrogen cycle [14]. On the other hand, phosphorus in sediments/suspended solids mainly exists in adsorbed, organic, iron-/aluminum-bound, and calcium-bound forms. However, only bioavailable nitrogen and phosphorus can promote algae growth and lead to eutrophication [15]. In recent years, most studies have focused on the forms of nitrogen and phosphorus that are most common in sediments. However, few studies have characterized these elements in suspended solids.

Suspended solids (SS) are among the most important elements of freshwater ecosystems, as they represent a substrate for nutrients to bind to $[16,17]$. The re-release of nitrogen and phosphorus in suspended solids is also one of the most important factors affecting the eutrophication of lakes. Suspended solids can easily adsorb contaminants (e.g., nutrients, heavy metals, organic contaminants) [18-21]. Moreover, suspended solids can exchange substances with water bodies during re-suspension, or reincorporate into the sediments after flocculation and sedimentation. On the other hand, the degradation of nutrients in suspended solids during suspension may lead to an accelerated migration of biogenic elements into the water bodies. These migrated elements can ultimately supplement the nutrients that are often depleted in summer due to blue-green algae blooms, and thus perpetuate algae bloom cycles. Therefore, studying the forms of nitrogen and phosphorus in suspended particulate matter is critical in establishing a theoretical basis for lake eutrophication control.

Taihu Lake, located in Jiangsu and Zhejiang province (i.e., the most economically developed areas of China), is among the five largest freshwater lakes in China. It represents the main drinking water source for Wuxi and Suzhou cities in Jiangsu province, and is one of the main water supplies for Shanghai and East Zhejiang province. However, with rapid urbanization, Taihu Lake has experienced numerous water pollution problems since the 1980s, particularly eutrophication and subsequent cyanobacterial blooms. Lihu Lake, a bay located in Wuxi City, is a typical shallow lake, with an average water depth of only $2.25 \mathrm{~m}[22,23]$. Wind and wave disturbances are prevalent and affect the water dynamics of the lake. Therefore, although water quality has been greatly improved due to the implementation of aquatic environment treatment projects, the concentration of suspended solids in the lake remains high. Large amounts of SS not only reduce the transparency and affect the underwater light conditions, but are also a great challenge for the drinking water of Wuxi City. However, previous studies on Lihu Lake mainly focused on the water quality [24], nitrogen and phosphorus forms in the sediment [25,26], etc. Although Lihu Lake has been subject to a series of abatement actions to restore the ecological environment, the content of suspended solids in this lake is still high, and the eutrophication still exists. Therefore, the study of nitrogen and phosphorus forms in suspended solids is of great significance for the further ecological restoration and environmental management of Lihu Lake. However, there are few studies on the forms of nitrogen and phosphorus in suspended solids of Lihu Lake. In this study, a nitrogen and phosphorus fractionation extraction approach based on improvements to previously reported methods was used to study the forms and spatial distributions of nitrogen and phosphorus in suspended solids in Lihu Lake. Particularly, this study sought to characterize the migration and transformation of nutrients between the water-SS and SS-sediment interfaces based on the following aspects: (1) Contents and spatial distribution of nitrogen and phosphorus forms in suspended solids, (2) correlations between all of the nitrogen and phosphorus forms in overlying water, suspended solids, and surface sediments, and (3) comparison between the nitrogen and phosphorus contents in suspended solids and surface sediments. 


\section{Materials and Methods}

\subsection{Study Area}

Lihu Lake $\left(120.22^{\circ} \mathrm{E}-120.29^{\circ} \mathrm{E}, 31.48^{\circ} \mathrm{N}-31.55^{\circ} \mathrm{N}\right)$ is located north of Taihu Lake, with a $6 \mathrm{~km}$ length from east to west and a $0.3-1.8 \mathrm{~km}$ width, covering an $8.6 \mathrm{~km}^{2}$ surface. The lake is connected to the Meiliang Bay of Taihu Lake, the Beijing-Hangzhou Grand Canal, and Gonghu Bay, which is relatively independent but still a part of Taihu Lake. In general, the overall flow rate of the study area is low. In the 1950s, Lihu Lake exhibited medium nutrient levels and was rich in aquatic plants and fisheries resources. Since then, the lake has provided drinking water for the entire city of Wuxi [27]. However, since the 1970s, the locals reclaimed land from the lake, and large-scale aquaculture farms were constructed. Additionally, vast amounts of domestic and industrial sewage from the surrounding areas began to be discharged into the lake. As a result, the total nitrogen (TN) and total phosphorus (TP) concentrations increased, and the water quality of the lake and its inflow rivers deteriorated rapidly, which has led to severe eutrophication. In 2001, the annual mean permanganate, total nitrogen (TN), total phosphorus (TP), and chlorophyll-a (Chl.a) index values were $7.80,6.38,0.20$, and $0.08 \mathrm{mg} / \mathrm{L}$, respectively, which were 1.39, 1.93, 2.44, and 2.61 times higher than the overall historical indices of Taihu Lake [28]. Therefore, starting in 2003, the Wuxi City government banned aquaculture, relocated the residents around the lake, and eliminated pollution sources to prevent further eutrophication of Lihu Lake. The central and local governments jointly implemented the "environmental dredging and ecological reconstruction project for heavily polluted water" in Lihu Lake, which entailed environmental dredging, vegetation reconstruction, and gate control or blockage of contaminated rivers. The water quality of Lihu Lake has since been maintained. However, water transparency and suspended solids have not improved significantly, and thus, nutrients in suspended solids may still aggravate the eutrophication process.

Nitrogen and phosphorus are the main pollutants affecting the water quality of Lihu Lake, and these contaminants originate from many external sources, as well as from endogenous release. Given that Lihu Lake is virtually isolated from the surrounding rivers by gates and dams, there is no water exchange between the lake and the surrounding rivers. The main sources of nitrogen and phosphorus in Lihu Lake are mainly internal and external sources through dry and wet deposition.

In this study, Lihu Lake was divided into four zones (A, B, C, and D), based on the physical boundaries within the study area (Lihu Dike, Baojie Bridge, and Lihu Great Bridge; Figure 1). Zone A used to contain a large number of fish ponds, which seriously polluted the lake, after which the surface sediments were removed by draining the lake water. Zone B was known as the "western Lihu Lake" before the implementation of comprehensive remediation measures via mechanical dredging. Moreover, aquatic vegetation reconstruction was implemented offshore. Zone C, bordered by the Baojie Bridge to the west and Lihu Great Bridge to the east (including Changguangxi Wetland Park), and also implemented the comprehensive coastal improvement project. Zone D, with more residential areas offshore, exhibits the worst water quality in Lihu Lake. 


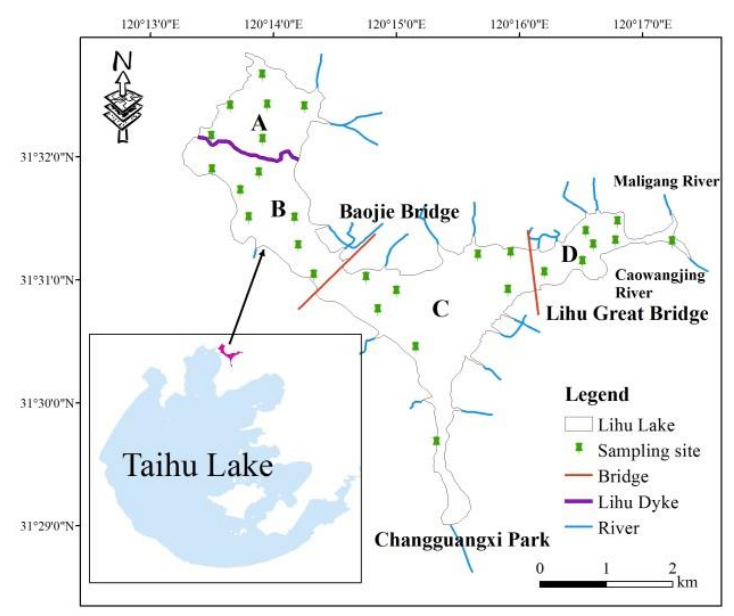

Figure 1. Location and sampling sites in Lihu Lake.

\subsection{Sampling and Sample Preparation}

Suspended solids and surface sediment samples from 28 sites (Figure 1) in Lihu Lake were collected in October 2019. A total of $50 \mathrm{~L}$ of water at a $0.5 \mathrm{~m}$ depth were collected from each sampling site into a clean and light-proof plastic sampling bottle which had been previously rinsed with Milli-Q. Water samples were filtered with glass fiber filters (GF/F) (Whatman, Maidstone, Kent County, U.K.) (these filters were pre-soaked in 1:1000 (v:v) $\mathrm{HCl}$ for $24 \mathrm{~h}$, then washed to neutral $\mathrm{pH}$ with Milli-Q water, and finally dried at $400^{\circ} \mathrm{C}$ for $5 \mathrm{~h}$ ) in situ to obtain wet suspended solid samples. These samples were then sent to the laboratory within $24 \mathrm{~h}$ at $-4{ }^{\circ} \mathrm{C}$ and vacuum freeze-dried at $-50{ }^{\circ} \mathrm{C}$ for $72 \mathrm{~h}$, then stored in dark, sealed bottles at $-4{ }^{\circ} \mathrm{C}$ until they were analyzed. At each site, the surface sediment samples were collected using a Petersen dredge. These samples were stored in clean black polythene bags at $-4{ }^{\circ} \mathrm{C}$ before being sent to the laboratory, vacuum freeze-dried at $-50{ }^{\circ} \mathrm{C}$, and ground through a 100 mesh sieve. The prepared samples were also stored in light-proof glass sealing bottles at $-4{ }^{\circ} \mathrm{C}$. In the field, water samples were filtered through pre-weighted filters (GF/F) (Whatman, Maidstone, Kent County, U.K.) to measure the suspended solid contents.

\subsection{Sample Analysis}

\subsubsection{Nitrogen Forms}

Based on sequential extraction, the nitrogen forms in suspended solids were divided into exchangeable nitrogen (EN), acid-hydrolyzable nitrogen $(\mathrm{HN})$, and residual nitrogen (RN). The sequential extraction steps for nitrogen forms and the measurement methods for each index are illustrated in Figure A1 (Appendix A).

\subsubsection{Phosphorus Forms}

According to the absorption and desorption characteristics of each phosphorus form in suspended solids, as well as their stability once combined with the suspended solids, and based on our improvements of previously published sequential extraction methods for phosphorus, our study divided inorganic phosphorus into weakly adsorbed inorganic phosphorus (WA- $\left.\mathrm{P}_{\mathrm{i}}\right)$, potentially active inorganic phosphorus (PA- $\left.\mathrm{P}_{\mathrm{i}}\right)$, iron $(\mathrm{Fe})$ - or aluminum $(\mathrm{Al})$-bound inorganic phosphorus $\left(\mathrm{Fe} / \mathrm{Al}-\mathrm{P}_{\mathrm{i}}\right)$, and calcium (Ca)-bound inorganic phosphorus $\left(\mathrm{Ca}-\mathrm{P}_{\mathrm{i}}\right)$. Moreover, the organic phosphorus forms were divided into weakly absorbed organic phosphorus $\left(\mathrm{WA}-\mathrm{P}_{\mathrm{o}}\right)$, potentially active organic phosphorus $\left(\mathrm{PA}-\mathrm{P}_{\mathrm{o}}\right)$, medium active organic phosphorus $\left(\mathrm{MA}-\mathrm{P}_{\mathrm{o}}\right)$, and non-active organic phosphorus (NA- $\mathrm{P}_{\mathrm{o}}$ ). Among these, MA- $\mathrm{P}_{\mathrm{o}}$ includes medium active organic phosphorus, which can be extracted with a sodium hydroxide $(\mathrm{NaOH})$ solution $\left(\mathrm{MA}_{\mathrm{NaOH}-\mathrm{Po}}\right)$, as well as non-active organic phosphorus, which can be extracted with a sodium hydroxide $(\mathrm{NaOH})$ solution $\left(\mathrm{NA}_{\mathrm{NaOH}-\mathrm{Po}}\right)$, and residual phosphorus 
$\left(\mathrm{R}-\mathrm{P}_{\mathrm{o}}\right)$. The sequential phosphorus extraction steps and the measurement methods for each index are shown in Figure A2 (Appendix A).

Nitrogen and phosphorus forms in the surface sediments were also extracted according to the aforementioned method. The measurement method of each index in the overlying water, suspended solids, and surface sediments was performed as described by Wang [25] and Wang [26].

\subsection{Quality Assurance and Quality Control (QA/QC)}

The analytical data quality was assessed by implementing quality assurance and quality control $(\mathrm{QA} / \mathrm{QC})$ procedures, including analysis of reagent blanks, duplicate samples, and standard reference materials (GSD-3a) for each sample batch. The analytical precision for replicate samples was within $\pm 10 \%$ and the measurement errors between determined and certified values were less than $5 \%$.

Statistical analyses of mean values and standard deviations were performed using the SPSS 22.0 software (IBM, Armonk, USA). The Kriging method was employed using ArcGIS 10.2 (ESRI, Redlands, USA) and Surfer 11 (Golden Software, Golden, USA) to map the spatial distribution of nitrogen and phosphorus forms. Other experimental data graphs were created with Excel 2010 (Microsoft, Redmond, USA) and Origin 2020 (OriginLab, Northampton, USA).

\section{Results and Discussion}

\subsection{Spatial Distribution of Total Suspended Solids}

The term "suspended solids" (SS) generally refers to plankton and inanimate particles suspended in water. Notably, the total suspended solid (TSS) content is not only positively correlated with nutrient levels, but is also positively correlated with total phosphorus (TP) contents in water. Therefore, TSS is often used as a reference index to reflect the level of nutrients in water. In 65 oligotrophic lakes in the USA and Argentina, the average annual mean TSS value was only $1.00 \mathrm{mg} / \mathrm{L}$ [29], whereas this value has been reported to be as high as $7.3 \mathrm{mg} / \mathrm{L}$ in 86 eutrophic shallow lakes in Europe [30]. However, the average TSS value in highly eutrophic shallow lakes in Denmark was as high as $22 \mathrm{mg} / \mathrm{L} \mathrm{[31].} \mathrm{As}$ shown in Figure 2, in this study, the average TSS value in Lihu Lake was $27 \mathrm{mg} / \mathrm{L}$, which is similar to that of 15 highly eutrophic shallow lakes in Denmark and West Lake in Hangzhou (25.02 mg/L) [32]. Nonetheless, the aforementioned value was lower than those of Taihu Lake (32.32 mg/L) [33] and Chaohu Lake (43.61 mg/L) [34], which are more eutrophic.

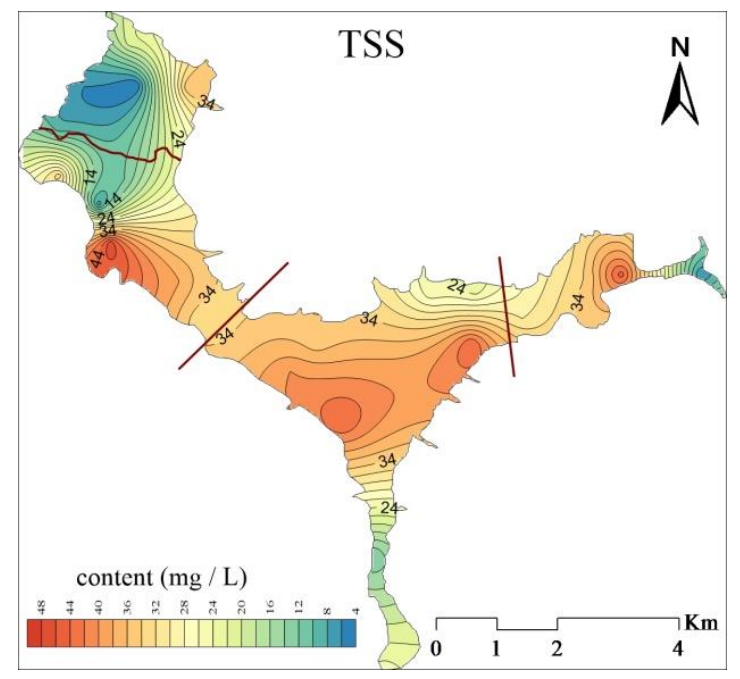

Figure 2. Spatial distribution of total suspended solids (TSS) in Lihu Lake.

Since Lihu Lake is isolated from the surrounding rivers by gate and dams, the particle solids from the surrounding rivers can be ignored. Therefore, planktonic algae proliferation, residues of 
aquatic plants, and sediment resuspension are the main factors influencing the TSS concentration in water. Due to an ecological reconstruction project, a considerable area of submerged plants has been planted in Zone A, and the contents of SS in these areas are lower than those in other areas. The main reason is that the submerged plants can not only adsorb the suspended solids, but also compete with phytoplankton for nutrients and light, thus inhibiting the growth of algae further.

As summarized in Table A1 (Appendix A), the particulate nitrogen (PN) and particulate phosphorus (PP) fractions were $0.06-0.71$ and $0.04-0.21 \mathrm{mg} / \mathrm{L}$, respectively, with average values of 0.35 and $0.11 \mathrm{mg} / \mathrm{L}$, accounting for $65.03 \%$ and $82.63 \%$ of the total nitrogen and total phosphorus contents, respectively. Moreover, the TSS value was found to have a positive correlation with the concentrations of $\mathrm{PP}(\mathrm{r}=0.260, \mathrm{n}=28)$ and TP $(\mathrm{r}=0.331, \mathrm{n}=28)$ (Figure A3).

\subsection{Spatial Distribution of Nitrogen Forms in Suspended Solids}

\subsubsection{Spatial Distribution of Exchangeable Nitrogen (EN) in Suspended Solids}

Figure 3 illustrates the spatial distribution characteristics of the exchangeable nitrogen forms in suspended solids of Lihu Lake. Exchangeable nitrogen in suspended solids mainly includes exchangeable $\mathrm{NH}_{4}{ }^{+}-\mathrm{N}\left(\mathrm{E}-\mathrm{NH}_{4}{ }^{+}-\mathrm{N}\right), \mathrm{NO}_{3}{ }^{-}-\mathrm{N}\left(\mathrm{E}-\mathrm{NO}_{3}{ }^{-} \mathrm{N}\right)$, and exchangeable soluble organic nitrogen $(\mathrm{SON})$. Exchangeable nitrogen in suspended solids can maintain dynamic equilibrium with the overlying water and surface sediments through adsorption/desorption, ion exchange, and biological disturbances [35]. Importantly, it represents a nutrient source that can be directly utilized by primary producers in lakes [36]. Therefore, the amounts of EN in SS play an extremely important role in the nitrogen cycle of suspended solids.

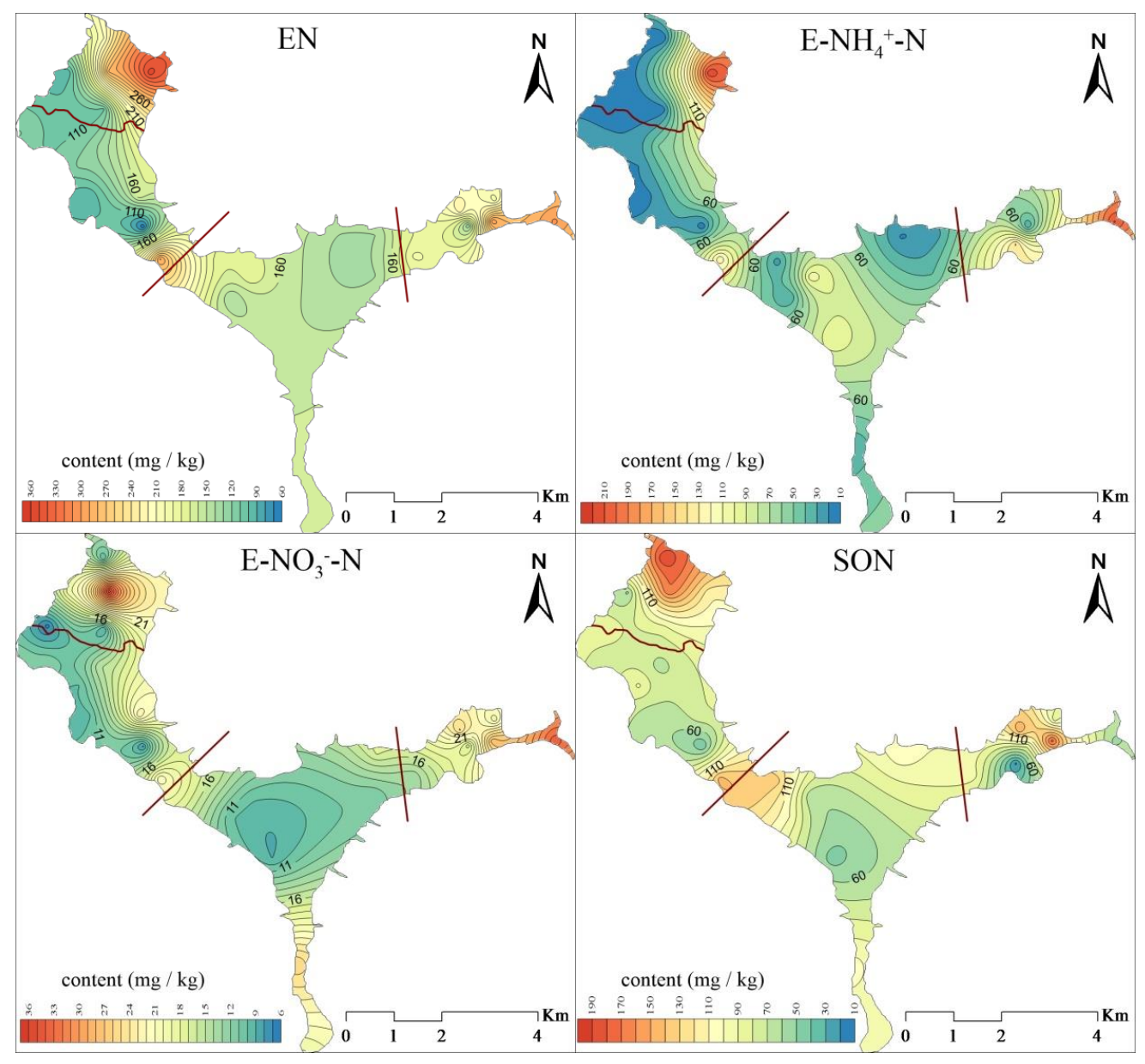

Figure 3. Spatial distribution of exchangeable nitrogen (EN) in suspended solids of Lihu Lake. 
As shown in Figure 3, the spatial distribution characteristics of exchangeable nitrogen in suspended solids of Lihu Lake were largely uniform. Overall, the contents in the estuary were higher than in the central lake. The estuary is constantly subjected to water disturbances, which are conducive to the adsorption of $\mathrm{NH}_{4}{ }^{+}-\mathrm{N}$ and $\mathrm{NO}_{3}{ }^{-}-\mathrm{N}$ onto suspended solids, resulting in high EN contents in the bay, with only slight differences between the studied zones. Nonetheless, the spatial distribution was ranked as follows: Zone $\mathrm{D}>\mathrm{C}>\mathrm{B}>\mathrm{A}$. Currently, a large number of submerged plants has been identified in Zone A, including Myriophyllum verticillatum, Hydrilla verticillata, and Vallisineria spiralis. However, other floating plants, such as Hydrocharis dubia, water hyacinth, and water chestnut, have been identified in other zones. Compared with floating plants, submerged plants have a relatively longer growth cycle, and their resulting detritus exists as organic nitrogen, which can only be released through mineralization. Furthermore, even after being released, it can be easily absorbed by aquatic plants to synthesize the substances that they need, which results in low nitrogen contents in the suspended solids of Zone A. Moreover, environmental dredging projects were carried out in Zones A and B to remove a large amount of pollutants from the sediment, which led to a significant reduction in nitrogen and phosphorus loads in sediments, as well as a reduction in re-suspension. Sediment dredging has also been carried out in some parts of Zone C. Additionally, Changguangxi is rich in aquatic plants, and the resulting macrophyte decay has increased the nitrogen loads in this area. Zone $\mathrm{D}$ is greatly affected by urban sewage, which causes a large amount of nutrients to be imported into the lake, and also increases the re-suspension of sediments. Zone $\mathrm{D}$ has not yet been subjected to large-scale sediment dredging, and, therefore, the nitrogen content in this zone is relatively high, resulting in a significantly higher EN content.

The EN concentration of the suspended solids of Lihu Lake ranged from 63.5 to $354.4 \mathrm{mg} / \mathrm{kg}$ (dry weight, the concentration for the solid fraction in this study is all dry weight), with a mean value of $174.4 \mathrm{mg} / \mathrm{kg}$. The most heavily polluted were the northeastern regions of Zones A and D, whereas the areas with less pollution were mainly concentrated in the western regions of Zones A and B. Compared with other studies [37], the concentration of EN in suspended solids was higher. This could be because, after the submerged plant restoration project and fish regulation project, massive residues produced by the death of plants and fish accumulated on the surfaces of the suspended solids, resulting in high SON contents in the suspended solids. The main EN form is SON, which ranges from 17.6 to $187.9 \mathrm{mg} / \mathrm{kg}$, with a mean value of $94.7 \mathrm{mg} / \mathrm{kg}$, accounting for $54.3 \%$ of the EN. SON is mainly composed of free amino acids, amino sugars, urea, and low-molecular-weight organic acids, and is an important part of EN. Additionally, it plays a significant role in the mineralization, immobilization, migration, and transformation of nitrogen [38]. The organic matter (OM) in suspended solids forms a large amount of $\mathrm{NH}_{4}{ }^{+}-\mathrm{N}$ via mineralization, which is then distributed between the overlying water-suspended

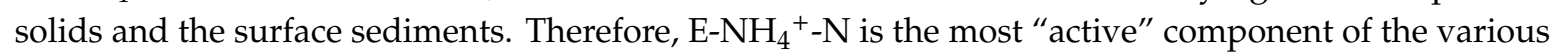
forms of nitrogen in suspended solids. The maximum value of $\mathrm{E}-\mathrm{NH}_{4}{ }^{+}-\mathrm{N}$ was $218.1 \mathrm{mg} / \mathrm{kg}$, whereas the minimum value was $10.86 \mathrm{mg} / \mathrm{kg}$; the mean value was $62.9 \mathrm{mg} / \mathrm{kg}$, accounting for $36.1 \%$. Compared with other forms of nitrogen, the $\mathrm{E}-\mathrm{NO}_{3}{ }^{-}-\mathrm{N}$ content was relatively low. Specifically, its mean value was $16.8 \mathrm{mg} / \mathrm{kg}$, accounting for only $9.6 \%$ of the EN.

\subsubsection{Spatial Distribution of Acid-Hydrolyzable Nitrogen (HN) in Suspended Solids}

The acid-hydrolyzable nitrogen $(\mathrm{HN})$ in the suspended solids is a kind of nitrogen form that can be transformed after mineralization and then released into the overlying water. HN mainly exists in the form of organic nitrogen. The most identifiable organic compounds in $\mathrm{HN}$ are amino acid nitrogen (AAN), amino sugar nitrogen (ASN), ammonium nitrogen (AN), and acid-hydrolyzable unknown nitrogen-containing compounds (HUN) [39]. Figure 4 illustrates the spatial distribution of all forms of $\mathrm{HN}$ in suspended solids of Lake Lihu. 


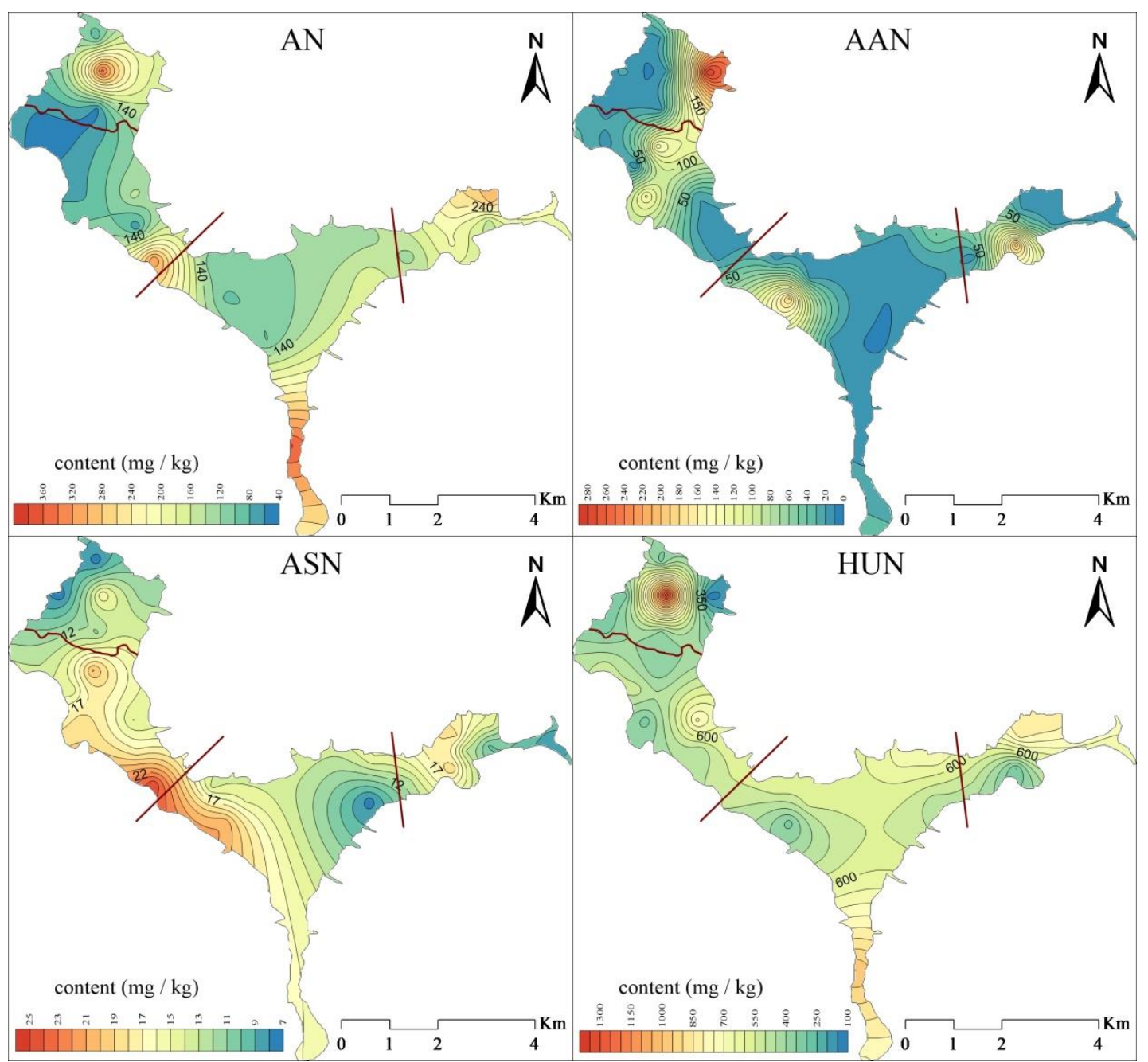

Figure 4. Spatial distribution of acid-hydrolyzable nitrogen (HN) in suspended solids of Lihu Lake.

The spatial distribution of various forms of $\mathrm{HN}$ at each sampling site was different. The mean values of AN, AAN, ASN, and HUN were 152.4, 50.6, 14.3, and $561.3 \mathrm{mg} / \mathrm{kg}$, respectively. HUN had a lower decomposition degree than other $\mathrm{HN}$ forms such as $\mathrm{AN}$, and belonged to the form that was not easily mineralizable. However, HUN decreased as the soil mineralization test proceeded. This indicates that HUN can also become bioavailable through biodegradation [40]. HUN had the highest proportion of $\mathrm{HN}(72.1 \%)$, followed by AN and AAN (19.6\% and 6.5\%, respectively). The suspended solids produce a certain amount of AN during the process of acid hydrolysis. The proportion of AN in the sampling sites of the eastern Zone A, the western Zone B, and the northern Zone D was relatively high, exceeding $28 \%$ in all cases. According to Wang et al. [41], AN is positively correlated with fixed ammonium nitrogen and organic matters. Therefore, we can infer that the organic matter and fixed ammonium nitrogen contents in suspended solids are important factors affecting AN. AAN (i.e., one of the most identifiable nitrogen-containing organic compounds), which is a kind of mineralizable nitrogen, and also a kind of stable SON [42]. Amino acids are mainly derived from proteins and polypeptides in organic matters. Thus, the OM content and its compounds will likely affect AAN contents directly. Suspended solid ASN mainly originates from the cell contents of microorganisms and aquatic insects. Its main component is glucosamine, followed by lactosamine; in fact, the sum of these two amines is close to the amount of nitrogen in the amino sugar fraction [43]. The results show that amino sugars are rarely found in higher plants [44,45], and are instead mainly concentrated in the chitin of microorganisms and insects. ASN represented the smallest fraction, with only $1.84 \%$. 
The mean values of HN in Zones A, B, C, and D were 681.9, 697.3, 814.9, and $903.5 \mathrm{mg} / \mathrm{kg}$, respectively. Moreover, the spatial distribution was ranked as Zone $\mathrm{D}>\mathrm{C}>\mathrm{B}>\mathrm{A}$.

\subsubsection{Spatial Distribution of Residual Nitrogen (RN) and Total Nitrogen (TN) in Suspended Solids}

Figure 5 illustrates the spatial distribution of residual nitrogen $(\mathrm{RN})$ and total nitrogen (TN) in suspended solids.

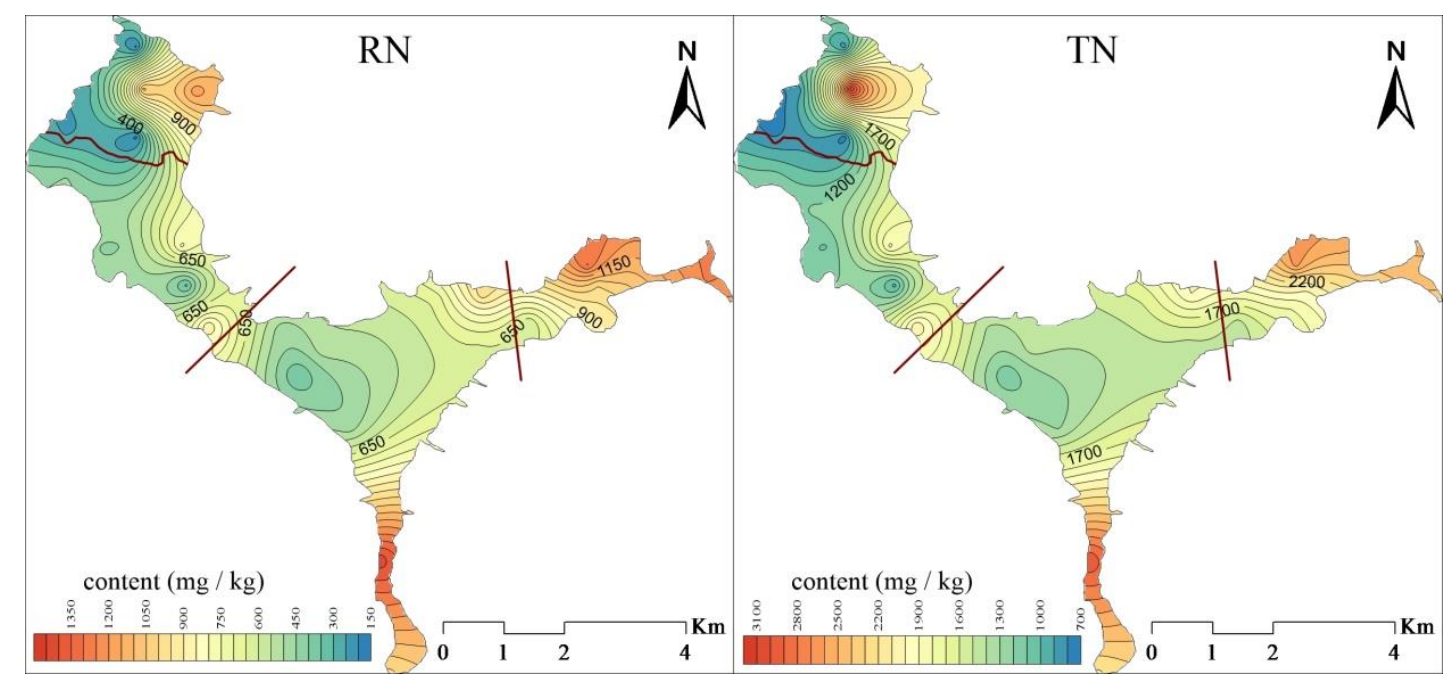

Figure 5. Spatial distribution of residual nitrogen $(\mathrm{RN})$ and total nitrogen $(\mathrm{TN})$ in suspended solids in Lihu Lake.

$\mathrm{RN}$ in suspended solids is mainly comprised of organic heterocyclic compounds or organic nitrogen-bound compounds with heterocyclic or aromatic rings [44]. This nitrogen fraction mainly comes from humic structural compounds with a higher degree of condensation. The RN content was found to be $189.0-1435.0 \mathrm{mg} / \mathrm{kg}$, with a mean value of $710.3 \mathrm{mg} / \mathrm{kg}$. The highest RN content was observed in the Changguangxi Bridge sampling site, which is in the south of Lihu Lake, followed by the Jincheng Bay sampling site in the eastern Lihu Lake. Zone A exhibited the lowest RN mean value $(517.8 \mathrm{mg} / \mathrm{kg}$ ). The RN spatial distribution increased from west to east (Zone D > C > B > A).

The TN content in suspended solids ranged from 758.9 to $3098.1 \mathrm{mg} / \mathrm{kg}$, with a mean value of $1663.2 \mathrm{mg} / \mathrm{kg}$. Moreover, the spatial distribution of TN content in suspended solids varied greatly. The TN content in the eastern Zone A was the highest, exhibiting concentrations that were 1.86 times higher than the mean value of the entire lake. The mean values of the four zones (A, B, C, D) were $1380.2,1403.6,1663.0$, and $2168.9 \mathrm{mg} / \mathrm{kg}$, respectively.

The average proportions of various nitrogen forms in each zone are illustrated in Figure 6. Based on the proportion of the content of each nitrogen form in the TN, $\mathrm{HN}$ had the highest proportion, accounting for $28.4-60.8 \%$, with an average of $48.4 \%$, followed by $\mathrm{RN}$, accounting for $22.2-55.0 \%$, with an average of $40.55 \%$. EN had the smallest proportion, accounting for only $11.03 \%$. The content of EN in Area D was relatively high, which was likely due to the high TN content in the overlying water of Zone D. This conclusion was based on the Surface Water Environment Quality Standard of China, which classified the aforementioned area as Class IV-V. The suspended solids adsorb inorganic nitrogen (e.g., ammonia nitrogen and nitrate nitrogen) onto the surfaces of the particles via exchangeable adsorption. 


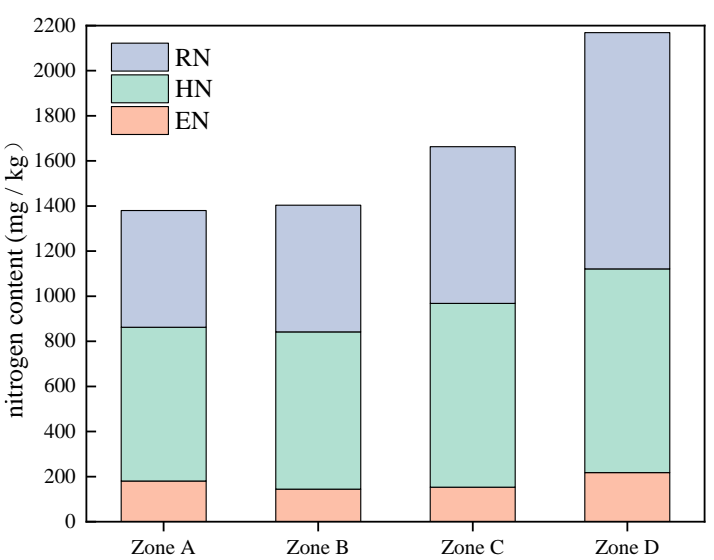

Figure 6. Contents of various nitrogen forms in each zone.

\subsection{Spatial Distribution of Phosphorus Forms in Suspended Solids}

\subsubsection{Spatial Distribution of Inorganic Phosphorus in Suspended Solids}

The spatial distribution of weakly adsorbed inorganic phosphorus (WA- $\mathrm{P}_{\mathrm{i}}$ ), potentially active inorganic phosphorus $\left(\mathrm{PA}-\mathrm{P}_{\mathrm{i}}\right)$, iron $(\mathrm{Fe})$ - or aluminum $(\mathrm{Al})$-bound inorganic phosphorus $\left(\mathrm{Fe} / \mathrm{Al}-\mathrm{P}_{\mathrm{i}}\right)$, and calcium (Ca)-bound inorganic phosphorus $\left(\mathrm{Ca}-\mathrm{P}_{\mathrm{i}}\right)$ is shown in Figure 7. As illustrated in Figure 7, the inorganic phosphorus contents in the suspended solids of Lihu Lake exhibited overall lower concentrations in the west than in the east, and the highest values were mostly concentrated in Zone D.

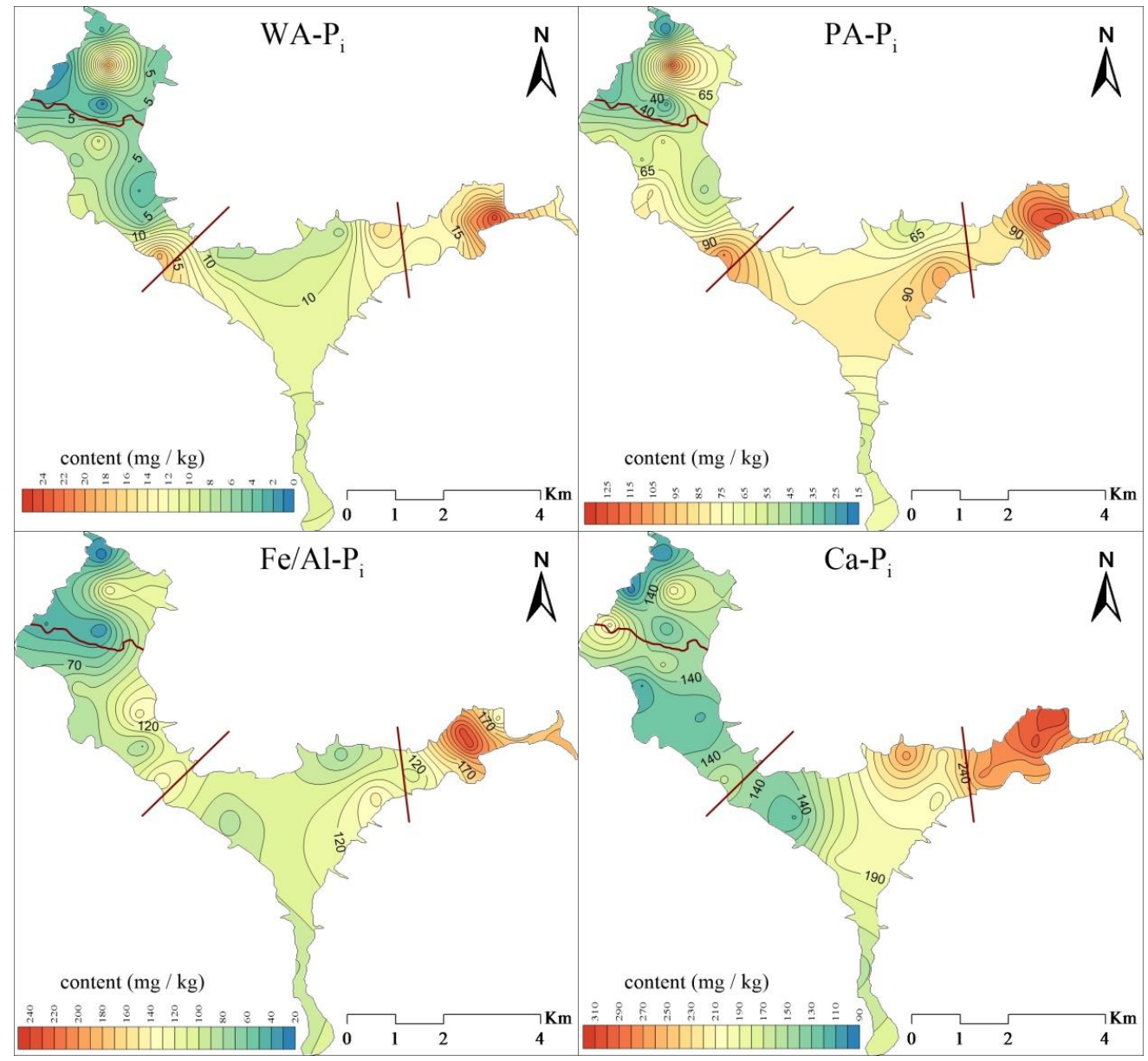

Figure 7. Spatial distribution of inorganic phosphorus in suspended solids of Lihu Lake. 
WA-P $\mathrm{P}_{\mathrm{i}}$ is mainly derived from interstitial water or inorganic phosphorus types that adhere to other phases, such as carbonate, oxide, hydroxide, or clay mineral particles, in a physically adsorbed state, and is thus a form of phosphorus that can be easily transported [46,47]. The WA- $P_{i}$ content in suspended solids of Lihu Lake ranges from 0.6 to $24.7 \mathrm{mg} / \mathrm{kg}$, with a mean value of $10.3 \mathrm{mg} / \mathrm{kg}$. Notably, its fraction only accounts for $2.7 \%$ of the total inorganic phosphorus and $1.6 \%$ of the total phosphorus. The highest values of WA-P $P_{i}$ occurred in the central region of Zone A and Zone $D$, whereas the lowest values were mainly concentrated in the western part of Zone A and Zone B in western Lihu Lake.

PA- $\mathrm{P}_{\mathrm{i}}$ in suspended solids refers to the fraction of active Fe-P and Al-P salts leached by a $\mathrm{NaHCO}_{3}$ solution during hydrolysis. PA- $P_{i}$ can be used as an effective indicator of the bioavailable phosphorus content in suspended solids [48]. In this study, PA- $\mathrm{P}_{\mathrm{i}}$ content in the suspended solids ranged from 19.3 to $128.6 \mathrm{mg} / \mathrm{kg}$, with an arithmetic mean value of $75.2 \mathrm{mg} / \mathrm{kg}$. This proportion accounted for $19.68 \%$ of the inorganic phosphorus and $11.71 \%$ of total phosphorus.

$\mathrm{Fe} / \mathrm{Al}-\mathrm{P}_{\mathrm{i}}$ refers to the inorganic phosphorus extracted by a $\mathrm{NaOH}$ solution, and includes phosphorus combined with $\mathrm{Fe} / \mathrm{Al}$ oxides or hydroxides. When the suspended solid overlying water interface is under anaerobic conditions, $\mathrm{Fe} / \mathrm{Al}-\mathrm{P}_{\mathrm{i}}$ can be converted into soluble phosphorus, which is then recycled into the water column [49]. The Fe/Al-P $P_{i}$ content was $21.9-236.1 \mathrm{mg} / \mathrm{kg}$, with a mean value of $111.1 \mathrm{mg} / \mathrm{kg}$.

Ca- $P_{\mathrm{i}}$ refers to the phosphorus fraction in the sediments that is associated with phosphorus-bearing minerals, such as authigenic apatite, calcium carbonate deposits, or biological skeletons [50]. Notably, this fraction is known to be released in acidic environments. However, the $\mathrm{pH}$ of the lake's suspended solids is generally weakly alkaline, and thus has little effect on the release of Ca- $\mathrm{P}_{\mathrm{i}}$ from the suspended solids to the water column. Therefore, Ca- $P_{\mathrm{i}}$ in the suspended solids is not readily bioavailable to aquatic organisms. Ca- $P_{i}$ contents were found to range from 93.9 to $307.8 \mathrm{mg} / \mathrm{kg}$, with a mean value of $185.4 \mathrm{mg} / \mathrm{kg}$.

\subsubsection{Spatial Distribution of Organic Phosphorus in Suspended Solids}

Figure 8 illustrates the spatial distribution of organic phosphorus in suspended solids. Similarly to $W A-P_{i}$, weakly absorbed organic phosphorus $\left(W A-P_{0}\right)$ is also derived from interstitial water or an organic phosphorus form that adheres to other phases, such as carbonate, oxide, hydroxide, and clay ore particles, by physical adsorption. Additionally, it is a form that is extremely easy to mineralize and transfer [51]. In this study, the content of WA-P $\mathrm{P}_{\mathrm{o}}$ in suspended solids of Lihu Lake ranged from 1.9 to $11.0 \mathrm{mg} / \mathrm{kg}$, with an average value of $4.7 \mathrm{mg} / \mathrm{kg}$.

The potentially active organic phosphorus $\left(\mathrm{PA}-\mathrm{P}_{\mathrm{o}}\right)$ fraction is mainly comprised of phosphorus-containing compounds, such as nucleic acids, phospholipids, and phosphosaccharides extracted from $\mathrm{NaHCO}_{3}$ solutions. [52,53]. Moreover, it can be used as an effective phosphorus source for the growth of phytoplankton and aquatic organisms. The PA- $\mathrm{P}_{\mathrm{o}}$ content in suspended solids of Lihu Lake ranged from 9.2 to $45.2 \mathrm{mg} / \mathrm{kg}$, with an average value of $24.4 \mathrm{mg} / \mathrm{kg}$.

Medium active organic phosphorus (MA- $\mathrm{P}_{\mathrm{o}}$ ) is the potentially bioavailable phosphorus form in suspended solids, which is composed of medium active organic phosphorus extracted by a $\mathrm{NaOH}$ solution $\left(\mathrm{MA}_{\mathrm{NaOH}-\mathrm{Po}}\right)$ and by a hydrochloric acid solution $\left(\mathrm{MA}_{\mathrm{HCl}-\mathrm{Po}}\right)$, including calcium phytate, magnesium phytate, and some phosphorus-containing compounds combined with fulvic acids. These compounds can be further decomposed into inorganic phosphorus through the action of hydrolases, such as phosphatase and phytase [54]. The average MA- $\mathrm{P}_{\mathrm{o}}$ value was $65.3 \mathrm{mg} / \mathrm{kg}$, ranging from 36.3 to $103.4 \mathrm{mg} / \mathrm{kg}$. 


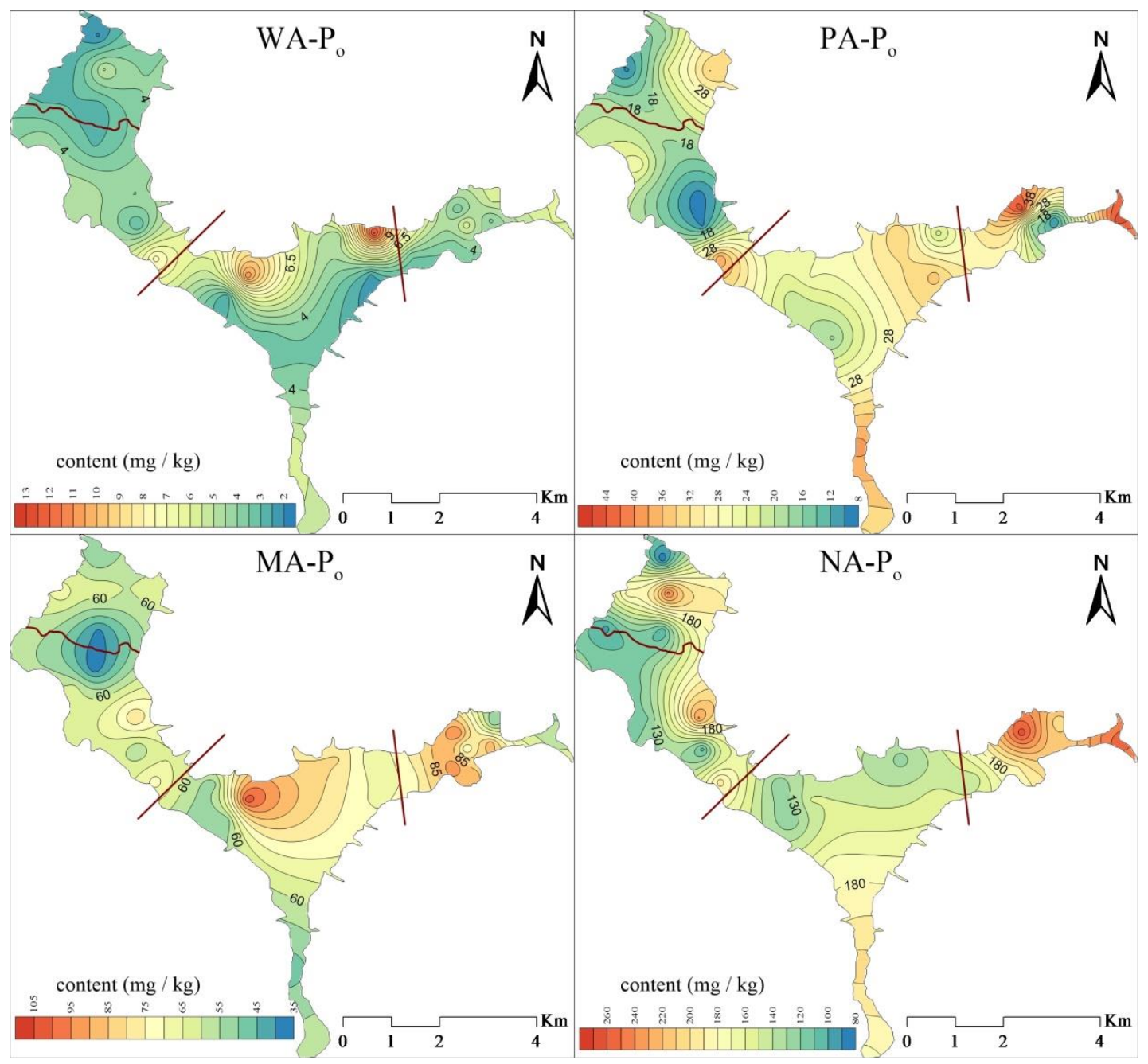

Figure 8. Spatial distribution of organic phosphorus in suspended solids of Lihu Lake.

Non-active organic phosphorus (NA- $\mathrm{P}_{\mathrm{o}}$ ) is a relatively stable phosphorus form in suspended solids, which is composed of non-active organic phosphorus extracted by $\mathrm{NaOH}$ solutions $\left(\mathrm{NA}_{\mathrm{NaOH}-\mathrm{Po}}\right)$ and residual phosphorus ( $\mathrm{R}-\mathrm{P}_{\mathrm{o}}$ ), including humic acid in humus, organic phosphorus in humin, iron-aluminum salts containing 4-6 kinds of phosphoric acids in inositol, and a small amount of phosphorus-containing aluminum or calcium encapsulated by an $\mathrm{Fe}_{2} \mathrm{O}_{3}$ adhesive film [55]. In this study, the range of NA- $\mathrm{P}_{\mathrm{o}}$ in suspended solids was $134.0-274.1 \mathrm{mg} / \mathrm{kg}$, and the average value was $172.3 \mathrm{mg} / \mathrm{kg}$, accounting for $67.7 \%$ of the total organic phosphorus and $25.1 \%$ of the total phosphorus. Additionally, the results demonstrated that the majority of NA-P $\mathrm{P}_{\mathrm{o}}$ was $\mathrm{R}-\mathrm{P}_{\mathrm{o}}$, and the proportion of R- $\mathrm{P}_{\mathrm{o}}$ in NA- $\mathrm{P}_{\mathrm{o}}$ ranged from $64.9 \%$ to $91.1 \%$, with an average of $80.4 \%$.

The total phosphorus contents of suspended solids in Lihu Lake were similar to those in the Taihu Lake basin [56]; when compared with the sediment in Taihu Lake [57], the contents were significantly higher.

The proportions of various phosphorus forms in each zone are illustrated in Figure 9. In this study, inorganic phosphorus was the primary form of phosphorus in suspended solids, with contents ranging from 144.1 to $684.5 \mathrm{mg} / \mathrm{kg}$, and an average of $381.9 \mathrm{mg} / \mathrm{kg}$, accounting for $58.6 \%$ of the total phosphorus. Inorganic phosphorus was dominated by Ca- $\mathrm{P}_{\mathrm{i}}$, accounting for $49.6 \%$ of the inorganic phosphorus fraction. Furthermore, organic phosphorus was mainly composed of $\mathrm{R}^{\mathrm{P}} \mathrm{P}_{\mathrm{o}}$ in inactive organic phosphorus, also accounting for more than $50 \%$ of the total organic phosphorus, which is consistent with previous studies [56]. Organic phosphorus (OP) mainly derives from terrestrial sources 
and biological processes, and OP content is generally regarded as a better eutrophication indicator than TP. In this study, the contents of inorganic and organic phosphorus with direct bioavailability ranged between $22.0-153.3$ and $12.6-51.2 \mathrm{mg} / \mathrm{kg}$, respectively, accounting for $7.5-18.3 \%$ and $1.5-7.4 \%$. The content of organic phosphorus with direct bioavailability was relatively low, which may be due to the strong interaction between the suspended solids and water in the lake. This facilitates the decomposition of WA- $\mathrm{P}_{\mathrm{o}}$ and PA- $\mathrm{P}_{\mathrm{o}}$ into small-molecule compounds or phosphate, which are then released into the overlying water.
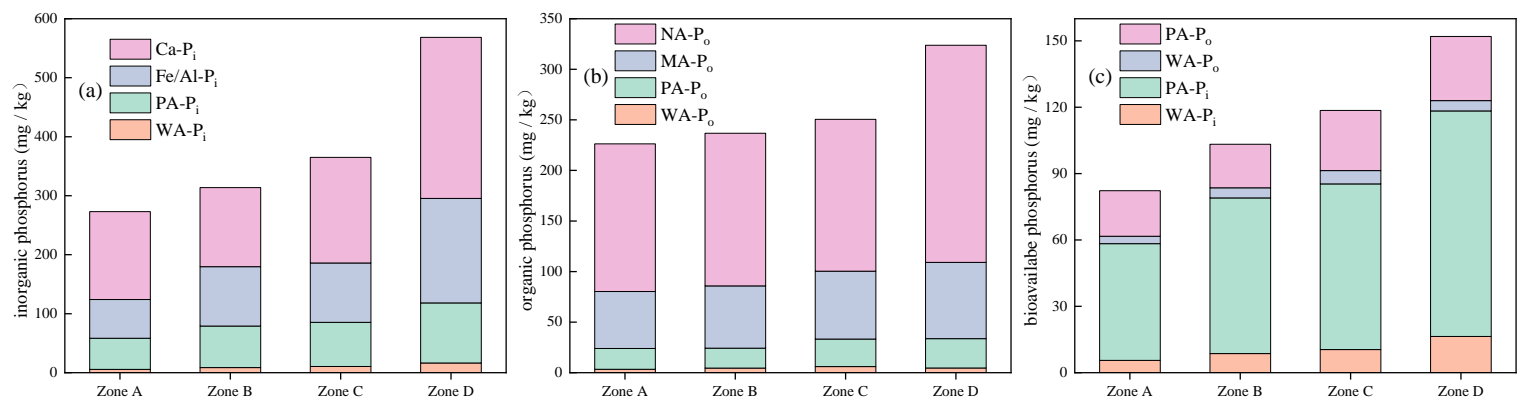

Figure 9. Contents of inorganic (a), organic (b), and bioavailable (c) phosphorus forms in each zone.

In nature, organic phosphorus occurs mainly in the form of monoester or diester phosphorus. Previous studies showed that hydroxyl-bound phosphorus in monoester and diester organic phosphorus has similar properties to those of orthophosphate, both of which absorb and desorb onto particles via hydroxyl-phosphorus interactions [58]. Furthermore, organic phosphorus shares similar adsorption and desorption mechanisms with inorganic phosphorus in suspended solids. In fact, phosphorus is always in a state of dynamic equilibrium between the suspended solids and overlying water. They can transform each other under certain conditions, and some forms of phosphorus in suspended solids can be released into the overlying water through physical, chemical, and biological processes, thereby adopting forms that can be readily utilized by organisms. In this study, we first observed that WA- $\mathrm{P}_{\mathrm{i}}$, WA- $\mathrm{P}_{\mathrm{O}}, \mathrm{PA}-\mathrm{P}_{\mathrm{i}}$, and PA-P $\mathrm{P}_{\mathrm{o}}$ were bioavailable phosphorus compounds that could be released into overlying water and participate in water recycling, which affects the nutritional status and primary productivity of the water body. Secondly, Fe/Al- $\mathrm{P}_{\mathrm{i}}$ and MA- $\mathrm{P}_{\mathrm{o}}$ can be converted under certain conditions. Specifically, Fe/Al- $\mathrm{P}_{\mathrm{i}}$ can be released to meet the needs of plankton growth when the suspended solid-water interface presents anaerobic conditions, whereas MA- $\mathrm{P}_{\mathrm{o}}$ can directly generate inorganic phosphorus under the action of hydrolases, such as phosphatase and phytase, or otherwise be mineralized to soluble active phosphorus via microorganism activity. Generally, $\mathrm{Fe} / \mathrm{Al}-\mathrm{P}_{\mathrm{i}}$ and MA- $P_{o}$ are regarded as potentially bioavailable phosphorus forms $[59,60]$. Lastly, Ca- $P_{i}$ and NA-P $P_{o}$ are considered to be stable forms, and therefore cannot be easily converted into bioavailable phosphorus forms, especially in lakes that are already affected by eutrophication. Therefore, the bioavailability of various forms of phosphorus in suspended solids must be further studied via multiple methods, such as mineralization and enzymatic hydrolysis, in order to establish a better understanding of nutrient dynamics in eutrophic lakes.

\subsection{Correlation Analysis Indicative of Nutrient Sources}

Suspended solids in lakes originate from numerous sources, and the correlation between various forms of nitrogen and phosphorus can reflect the link between each fraction. Furthermore, this approach can reflect the sources of nitrogen and phosphorus forms in suspended solids to some extent. In order to explore the possible sources of nitrogen and phosphorus forms in suspended solids, Pearson correlation tests were conducted between all fractions. The analysis results are summarized in Table 1; Table 2. 
Table 1. Correlations between nitrogen forms in suspended solids.

\begin{tabular}{|c|c|c|c|c|c|c|c|c|c|c|c|}
\hline & ETN & E- $-\mathrm{NH}_{4}{ }^{+}-\mathrm{N}$ & $\mathrm{E}-\mathrm{NO}_{3}{ }^{-}-\mathrm{N}$ & SON & HN & AN & AAN & ASN & HUN & RN & TN \\
\hline ETN & 1 & & & & & & & & & & \\
\hline E-NH ${ }_{4}^{+}-\mathrm{N}$ & $0.794^{* *}$ & 1 & & & & & & & & & \\
\hline $\begin{array}{c}\mathrm{E}-\mathrm{NO}_{3} \\
\mathrm{NO}_{3}{ }^{-}-\mathrm{N}\end{array}$ & $0.736^{* *}$ & $0.549^{* *}$ & 1 & & & & & & & & \\
\hline SON & $0.539 * *$ & -0.078 & 0.359 & 1 & & & & & & & \\
\hline HN & 0.440 * & 0.198 & $0.759 * *$ & 0.365 & 1 & & & & & & \\
\hline AN & $0.577^{* *}$ & 0.403 * & $0.745^{* *}$ & 0.325 & $0.854^{* *}$ & 1 & & & & & \\
\hline AAN & 0.178 & 0.374 & -0.004 & -0.201 & -0.216 & -0.050 & 1 & & & & \\
\hline ASN & -0.045 & 0.030 & -0.039 & -0.115 & 0.218 & 0.234 & 0.301 & 1 & & & \\
\hline HUN & 0.265 & -0.014 & $0.630^{* *}$ & 0.371 & $0.929 * *$ & 0.659 ** & $-0.517 * *$ & 0.073 & 1 & & \\
\hline RN & $0.643^{* *}$ & $0.558 * *$ & $0.814^{* *}$ & 0.216 & $0.769 * *$ & $0.816^{* *}$ & 0.072 & 0.089 & $0.593^{* *}$ & 1 & \\
\hline TN & $0.656^{* *}$ & 0.481 ** & 0.862 ** & 0.338 & $0.911^{* *}$ & $0.888^{* *}$ & -0.036 & 0.140 & $0.764^{* *}$ & $0.959 * *$ & 1 \\
\hline
\end{tabular}

In Table 1, the numbers represent the mean correlation coefficients; ** means $p<0.01$, and indicates an extremely significant correlation; ${ }^{*}$ means $p<0.05$, and indicates a significant correlation. represents an extremely significant positive correlation; r represents a significant positive correlation; $\square$ represents a positive correlation; represents an extremely significant negative correlation; $\square$ represents a negative correlation.

Table 2. Correlations between phosphorus forms in suspended solids.

\begin{tabular}{|c|c|c|c|c|c|c|c|c|c|c|c|}
\hline & WA-P $\mathbf{P}_{\mathbf{i}}$ & $\mathbf{P A}-\mathbf{P}_{\mathbf{i}}$ & $\mathrm{Fe} / \mathrm{Al}-\mathrm{P}_{\mathrm{i}}$ & Ca-P $\mathbf{P}_{\mathbf{i}}$ & WA-P $P_{0}$ & PA-P & MA-P & NA-P & IP & OP & TP \\
\hline $\mathbf{W A}-\mathbf{P}_{\mathbf{i}}$ & 1 & & & & & & & & & & \\
\hline $\mathbf{P A} \mathbf{P}_{\mathbf{i}}$ & $0.910^{* *}$ & 1 & & & & & & & & & \\
\hline $\mathrm{Fe} / \mathrm{Al}-\mathrm{P}_{\mathbf{i}}$ & $0.728^{* *}$ & $0.817^{* *}$ & 1 & & & & & & & & \\
\hline Ca-P $\mathbf{P}_{\mathbf{i}}$ & $0.670^{* *}$ & $0.616^{* *}$ & $0.626^{* *}$ & 1 & & & & & & & \\
\hline WA-P & 0.344 & 0.234 & 0.201 & 0.142 & 1 & & & & & & \\
\hline PA-P & 0.256 & 0.293 & 0.374 & 0.332 & 0.209 & 1 & & & & & \\
\hline MA-P & 0.346 & 0.492 * & $0.563^{* *}$ & 0.419 * & 0.294 & 0.159 & 1 & & & & \\
\hline $\mathbf{N A}-\mathbf{P}_{\mathbf{o}}$ & $0.568^{* *}$ & $0.634^{* *}$ & $0.822^{* *}$ & 0.467 * & 0.181 & $0.377^{*}$ & $0.414^{*}$ & 1 & & & \\
\hline IP & $0.844^{* *}$ & $0.868^{* *}$ & $0.899 * *$ & $0.887^{* *}$ & 0.212 & 0.380 * & $0.529^{* *}$ & $0.707^{* *}$ & 1 & & \\
\hline OP & $0.588^{* *}$ & 0.663 ** & $0.856^{* *}$ & $0.530 * *$ & 0.285 & $0.499 * *$ & $0.612^{* *}$ & 0.960 ** & 0.757 ** & 1 & \\
\hline TP & $0.805^{* *}$ & $0.848^{* *}$ & $0.936^{* *}$ & $0.816^{* *}$ & 0.249 & 0.443 * & $0.588^{* *}$ & $0.834^{* *}$ & $0.975^{* *}$ & $0.884^{* *}$ & 1 \\
\hline
\end{tabular}

In Table 2, the numbers represent the mean correlation coefficients; ${ }^{* *}$ means $p<0.01$, and indicates an extremely significant correlation; ${ }^{*}$ means $p<0.05$, and indicates a significant correlation. $\quad$ represents an extremely significant positive correlation; $\square$ represents a significant positive correlation; $\square$ represents a positive correlation. 
The correlation analysis results showed that TN was significantly positively correlated with EN, $\mathrm{HN}$, and $\mathrm{RN}(p<0.01, \mathrm{n}=28)$. Among these, the correlation coefficient between TN and RN was the highest $(\mathrm{r}=0.959)$, indicating that the TN content in suspended solids was mainly modulated by RN.

E-TN is significantly positively correlated with E-NH ${ }_{4}{ }^{+}-\mathrm{N}, \mathrm{E}-\mathrm{NO}_{3}{ }^{-}-\mathrm{N}$, and E-SON $(p<0.01$, $\mathrm{n}=28)$. Among these, the correlation coefficient of E-TN and E- $\mathrm{NH}_{4}{ }^{+}-\mathrm{N}$ was the highest $(\mathrm{r}=0.794)$. Additionally, $\mathrm{E}-\mathrm{NH}_{4}{ }^{+}-\mathrm{N}$ was one of the main components of E-TN, and thus, it can be inferred that E-TN

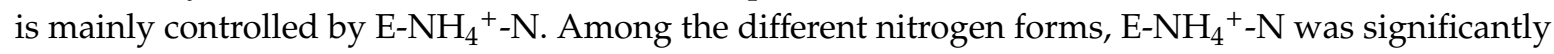

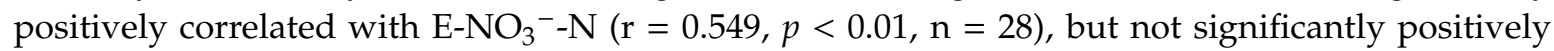
correlated with E-SON. This indicates that E- $\mathrm{NH}_{4}{ }^{+}-\mathrm{N}$ and E- $\mathrm{NO}_{3}{ }^{-}-\mathrm{N}$ can transform into each other under certain conditions., mainly because of the DO (Dissolved Oxygen) content in Lihu Lake (DO = 7.05), which facilitates denitrification. Moreover, there was no correlation between E-SON, E- $\mathrm{NH}_{4}{ }^{+}-\mathrm{N}$, and $\mathrm{E}-\mathrm{NO}_{3}{ }^{-}-\mathrm{N}$. This may be because the transformation between inorganic and organic nitrogen occurs mainly through anaerobic microorganism-mediated mineralization; however, the conditions in the overlying water were not favorable for the growth of anaerobic microorganisms. Furthermore, $\mathrm{H}-\mathrm{TN}$ was significantly positively correlated with AN and HUN $(\mathrm{r}=0.854, \mathrm{r}=0.929, p<0.01, \mathrm{n}=28)$, meaning that the amount of H-TN in suspended solids mainly depended on AN and HUN. Among the different nitrogen forms, only AN and HUN had a positive correlation $(r=0.659, p<0.01, n=28)$, indicating that the two forms may not only share a similar source, but frequent transformations likely occur between them. The correlations among the remaining forms were not significant, indicating that they may derive from different sources. Particularly, AAN and HUN showed a significant negative correlation ( $\mathrm{r}=-0.517, p<0.01, \mathrm{n}=28)$, suggesting that AAN and HUN may be antagonistic to each other or derive from different sources.

To explore the potential sources of phosphorus in suspended solids, a correlation analysis among the phosphorus forms was performed. There was a significant positive correlation between TP and inorganic phosphorus, as well as MA- $\mathrm{P}_{\mathrm{o}}$ and NA-P $\mathrm{P}_{\mathrm{o}}(p<0.01)$, meaning that the TP content was mainly affected by inorganic phosphorus, MA- $\mathrm{P}_{\mathrm{o}}$, and NA- $\mathrm{P}_{\mathrm{o}}$. Moreover, the correlation between TP and various forms of inorganic phosphorus was more significant, indicating that TP in suspended solids is mainly controlled by inorganic phosphorus. In other words, the various forms of inorganic phosphorus originate from sediment re-suspension. Furthermore, IP, MA-P $\mathrm{P}_{\mathrm{o}}$, and NA- $\mathrm{P}_{\mathrm{o}}$ were significantly positively correlated $(p<0.01)$, indicating that they may share the same source. Particularly, the correlation between WA- $\mathrm{P}_{\mathrm{i}}$ and PA-P $\mathrm{P}_{\mathrm{i}}$ with high biological activity was the most significant $(\mathrm{r}=0.910, p<0.01, \mathrm{n}=28)$, suggesting that these two forms likely share the same source. We also observed a significant correlation between OP and MA- $P_{0}$, as well as MA- $P_{0}$, and NA- $P_{0}(p<0.01)$. However, WA- $\mathrm{P}_{\mathrm{o}}$ did not have a significant correlation with the contents of other phosphorus forms. This may be because a fraction of OP is bioavailable phosphorus, which mainly comes from agricultural non-point source pollution [61]. However, NA-P $\mathrm{P}_{\mathrm{o}}$ mainly derives from insoluble phosphorus minerals, and, therefore, cannot be easily utilized by aquatic organisms. Based on these observations, we concluded that the sources of OP in suspended solids were quite variable in the studied lake.

Previous studies [62,63] showed that the dry and wet deposition amount of TN was $11.0 \mathrm{t} / \mathrm{a}$, whereas that of TP was $0.2 \mathrm{t} / \mathrm{a}$. Moreover, the release fluxes of nitrogen and phosphorus in sediments by resuspension were approximately 20-30 t/a and 1-2 t/a, respectively. The sum of the two accounted for more than $90 \%$ of the nitrogen and phosphorus loads in Lihu Lake. Dry and wet nitrogen deposition is mainly attributable to dissolved total nitrogen (DTN) $(91.4 \%)$, whereas the contribution of dissolved total phosphorus (DTP) to phosphorus deposition is relatively lower, with an average of $65.1 \%$. This is also consistent with the fact that TN was found to be mainly dissolved nitrogen, whereas TP was largely comprised of the particulates in the water of Lihu Lake. These observations also reflect the contribution of suspended solids to nitrogen and phosphorus pollution in Lihu Lake. The prevention and control of endogenous pollution in lakes is a complicated and difficult undertaking. Internal loading and eutrophication affect each other. Therefore, to improve the water quality of Lihu Lake, it is necessary 
to consider not only the interaction between water and sediments, but also the impact of suspended solids on pollution loads.

\subsection{Analysis of Influencing Factors}

Water is the medium that connects the various environmental components of a lake [64]. Therefore, the characteristics of the overlying water must have an important effect on the release of nitrogen and phosphorus in suspended solids. In order to further characterize the relationship between the overlying water, suspended solids, and surface sediments, Pearson's correlation analyses were conducted between physical and chemical indices and the nitrogen and phosphorus forms in suspended solids and surface sediments. The results are illustrated in Figure 10.
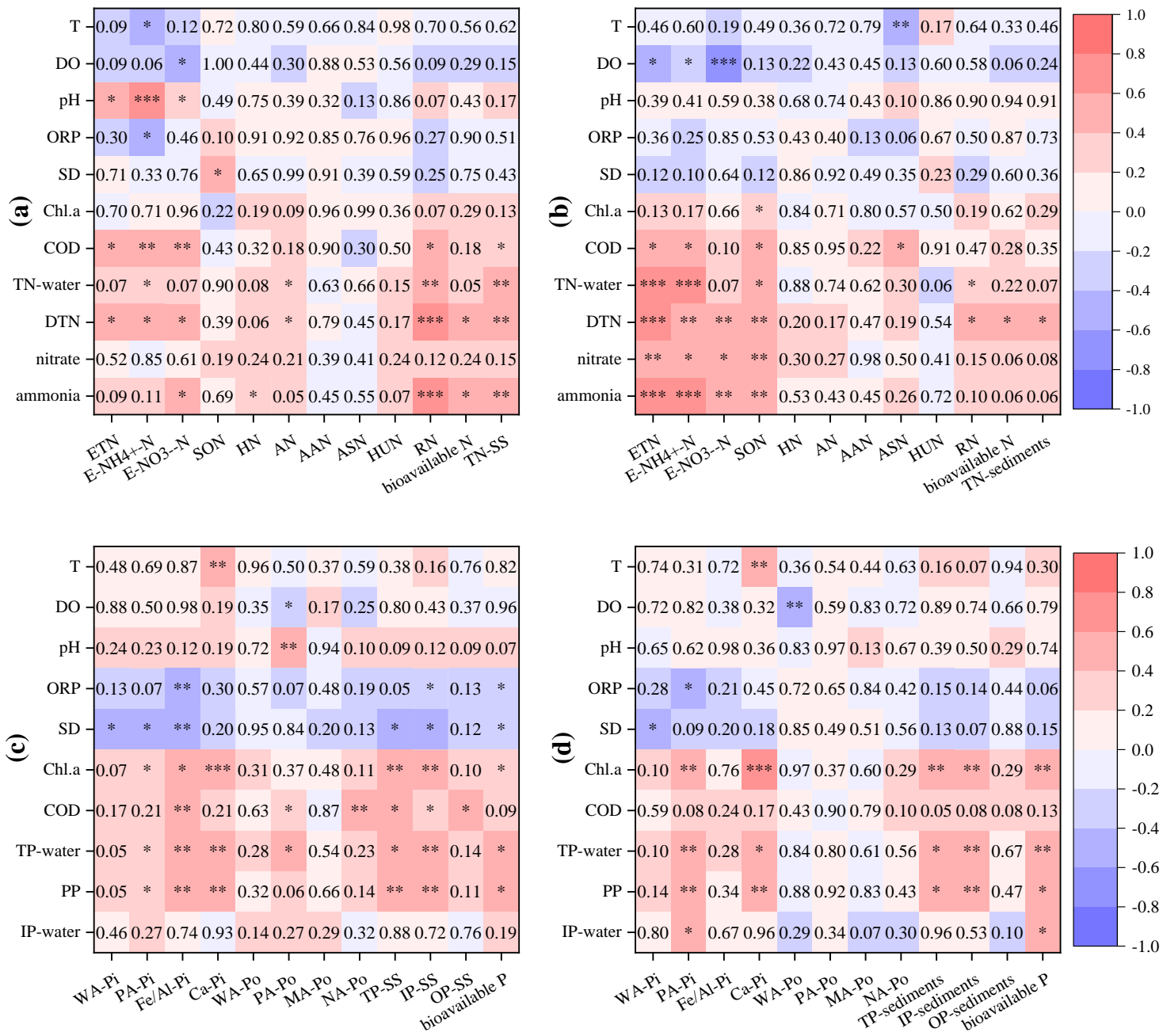

Figure 10. Relationships between nitrogen and phosphorus forms in suspended solids and surface sediments and physicochemical indices in water. The numbers in the figure indicate $p$ values. (a) correlation between nitrogen forms in suspended solids and water, (b) correlation between nitrogen forms in surface sediments and water, (c) correlation between phosphorus forms in suspended solids and water, (d) correlation between phosphorus forms in surface sediments and water. ${ }^{*}$ means $p<0.05$, ** means $p<0.01,{ }^{* * *}$ means $p<0.001$. Red cells indicate positive correlations and blue cells indicate negative correlations.

Although suspended solids have a strong capacity to release EN and HN, they exhibited no significant correlation with TN in overlying water. In contrast, RN in suspended solids showed a positive correlation with TN, DTN, and ammonium nitrogen in the overlying water. This was mainly 
because the EN and HN contents were less than that of RN, which also demonstrates that RN was the main nitrogen source in the overlying water. The content of bioavailable $\mathrm{N}$ forms in suspended solids is positively correlated with $\mathrm{NH}_{4}{ }^{+}-\mathrm{N}$ in the water, which means that under certain conditions, the suspended solids can affect the content of ammonia in water. $\mathrm{TN}$ and $\mathrm{NH}_{4}{ }^{+}-\mathrm{N}$ in the water had a significantly positive correlation with EN and E- $\mathrm{NH}_{4}{ }^{+}-\mathrm{N}$ in the surface sediments $(p<0.01)$, and this was consistent with Sun's [47] observations in Erhai Lake. EN is a nitrogen form that is easily released into the overlying water if the conditions are favorable. Therefore, this relationship indicated that the nitrogen in the overlying water mainly originated from the surface sediments, and the release of $\mathrm{NH}_{4}{ }^{+}-\mathrm{N}$ from surface sediments played an important role in the supply of $\mathrm{NH}_{4}{ }^{+}-\mathrm{N}$ to the overlying water. Both $\mathrm{NH}_{4}{ }^{+}-\mathrm{N}$ and $\mathrm{NO}_{3}{ }^{-}-\mathrm{N}$ in the surface sediment had significant correlations with HN. This indicates that the mineralization and decomposition of $\mathrm{HN}$ in the surface sediments is an important supplier to these two nitrogen forms, and can indirectly provide a continuous nitrogen source for overlying water. In suspended solids and surface sediments, various forms of nitrogen were mainly significantly linked to ammonium nitrogen in the overlying water, indicating that both of them contribute to the reduction of nitrogen in water to ammonia nitrogen. Some studies $[65,66]$ have shown that algae can selectively utilize nitrogen in water. This is because ammonium nitrogen does not need to be reduced when assimilated, whereas nitrate nitrogen needs to be reduced before its use. Therefore, ammonia nitrogen promotes the growth of algae more effectively. The inorganic nitrogen in water is mainly composed of ammonia nitrogen, which is not correlated with the concentration of suspended solids. Therefore, although the RN content in suspended solids is significantly positively correlated with ammonia nitrogen $(p<0.01)$, RN cannot be directly converted to ammonia nitrogen and, consequently, suspended solids cannot directly promote algae growth. Therefore, we can infer that the sediment has a greater effect on the nitrogen in water compared with suspended solids. In contrast, high concentrations of suspended solids lead to water turbidity, thereby limiting algae photosynthesis and inhibiting their growth to some extent.

Chlorophyll a (Chl.a) is an important indicator of primary productivity. In this study, the correlation coefficients between Chl.a and various forms of phosphorus in suspended solids were all found to be positive. Among them, the correlation coefficient between Chl.a and inorganic phosphorus was the highest $(r=0.567)$. In other words, when the external environment changes, part of the inorganic phosphorus fraction is released, thereby increasing the content of phosphorus in water. Algae are parts of the suspended solids; in the meanwhile, phosphorus in suspended solids plays an important role in algae growth. Particularly, its correlation coefficient with Ca- $\mathrm{P}_{\mathrm{i}}$ was the highest $(\mathrm{r}=0.616)$. This is because areas with high Chl.a contents are indicative of high photosynthetic activity and active phytoplankton growth, which translates to an accelerated rate of biological residue decomposition and a subsequent increase in Ca- $P_{i}$ that result from the combination of biological residues with calcium in the environment. The bioavailable phosphorus forms in the sediment can be released into the water, and then affect the algae growth. All of the nitrogen forms in suspended solids and sediment are not correlated with Chl.a, which means that nitrogen in suspended solids and sediment does not directly affect the primary productivity of the lake.

The correlation between the phosphorus components in the water and phosphorus forms in the suspended solids/surface sediments demonstrated that the content of phosphorus in water was affected by both suspended solids and sediment. $\rho(\mathrm{TP})$ in the overlying water was affected by various phosphorus forms in the suspended solids, especially inorganic phosphorus. Notably, particulate phosphorus (PP) was found to be the main component of TP in the overlying water, and $\rho(\mathrm{PP})$ was mainly affected by inorganic phosphorus in the suspended solids. Moreover, the correlation coefficient of $\mathrm{Fe} / \mathrm{Al}-\mathrm{P}_{\mathrm{i}}$ was the highest $(\mathrm{r}=0.503)$, indicating that $\mathrm{Fe} / \mathrm{Al}-\mathrm{P}_{\mathrm{i}}$ was the main form affecting TP content in the water. The increase of $\omega\left(\mathrm{PA}-\mathrm{P}_{\mathrm{i}}\right)$ in the surface sediments leads to increases in $\rho(\mathrm{IP})$ in the overlying water. This observation is highly relevant, as IP is known to be easily utilized by algae, which leads to cyanobacterial blooms. The bioavailable phosphorus forms in sediment affect the nutrient level by affecting the content of IP in water. 


\subsection{Comparison Analysis between Suspended Solids and Surface Sediments}

Nutrients in the sediments can be released into the overlying water through diffusion, convection, and other processes, causing secondary pollution [67]. Moreover, suspended solids are an important part of aquatic ecosystems, and their nutrient concentrations can reflect the water quality of a lake [68]. In order to more precisely control the endogenous pollution of a lake, it is necessary to compare the contents of various nutrient forms in suspended solids with those in surface sediments. These results are illustrated in Figure 11.
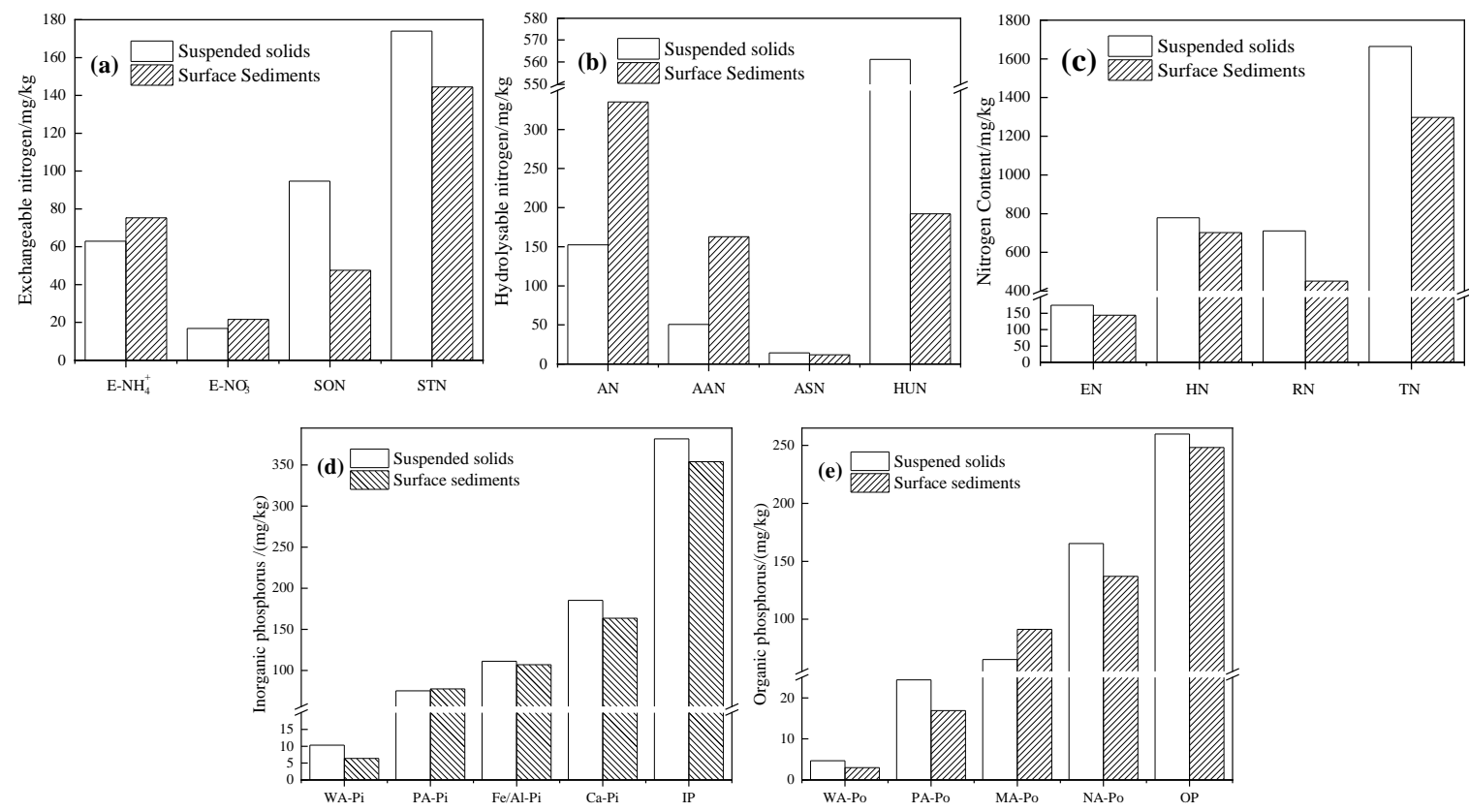

Figure 11. Comparison between the contents of nitrogen and phosphorus forms in the suspended solids with those in surface sediments.

Liu [69] examined the correlation between the content of various nitrogen forms and particle size in sediments of the Dan River. The results showed that finer sediment particles translated to higher contents of nitrogen forms. Therefore, the nitrogen adsorption capacity of suspended solids is stronger than that of surface sediments. Moreover, EN is the main and most active form involved in the transportation and migration of nitrogen in suspended solids/surface sediments. It is also the main source of bioavailable nitrogen in suspended solids and surface sediments, and the $\mathrm{NH}_{4}{ }^{+}-\mathrm{N}$ and $\mathrm{NO}_{3}{ }^{-}-\mathrm{N}$ content in suspended solids is typically lower than in surface sediments. This is because the nitrogen concentration in the interstitial water of surface sediments is higher than that in the overlying water due to the influence of $\mathrm{OM}$ degradation by benthic organisms. Therefore, suspended solids adsorb less $\mathrm{NH}_{4}{ }^{+}-\mathrm{N}$ and $\mathrm{NO}_{3} \mathrm{NO}_{3}{ }^{-}-\mathrm{N}$ than surface sediments. Moreover, low $\mathrm{O}_{2}$ concentrations in sediments favor the growth of denitrifying bacteria, thereby promoting the denitrification process and the subsequent accumulation of large amounts of $\mathrm{NH}_{4}{ }^{+}-\mathrm{N}$ in the surface sediments. Thus, the $\mathrm{NH}_{4}{ }^{+}-\mathrm{N}$ content was higher than that of $\mathrm{NO}_{3} \mathrm{NO}_{3}{ }^{-}-\mathrm{N}$. The OM content affects the number of adsorptive sites in sediments. Studies have shown that sediments with high organic matter contents have more adsorptive sites, which can adsorb more AN and AAN. In consequence, organic matter affects AN and AAN contents. The COD (Chemical Oxygen Demand) content in the overlying water of Lihu Lake $(\mathrm{COD}=4.41 \mathrm{mg} / \mathrm{L})$ is lower than that of the interstitial water. Therefore, the contents of AN and AAN in the suspended solids are lower than those of surface sediments. Generally speaking, there are three main sources of bioavailable nitrogen in suspended solids/surface sediments: Inorganic nitrogen $\left(\mathrm{NH}_{4}{ }^{+}-\mathrm{N}, \mathrm{NO}_{3}{ }^{-}-\mathrm{N}\right)$, dissolved organic nitrogen, and mineralizable organic nitrogen (mainly AAN). In this study, EN, AN, and AAN occurred as bioavailable 
nitrogen, and their contents in suspended solids were lower than those in surface sediments. In other words, the nitrogen in surface sediments was more bioavailable than that in suspended solids.

Upon comparing the $\mathrm{RN}$ content in the suspended solids with that in the surface sediments, we observed that the $\mathrm{RN}$ content in suspended solids of each sampling site was generally more than twice that of the surface sediments. This was because the oxidation environment of the suspended solids was likely stronger than that of surface sediments, and a strong oxidation environment enhances the stability of RN in sediments [70].

In general, the contents of various forms of phosphorus except for MA- $\mathrm{P}_{\mathrm{O}}$ in suspended solids were higher than in the surface sediments. That is, the phosphorus in suspended solids was more bioavailable than that in surface sediments. This relationship between suspended solids and surface sediments was consistent with the observations of Jin [37] and Zan [61]. This was mainly attributed to the continuous wind-wave disturbances in the studied sites, which cause the surface sediments to be constantly disturbed. For this reason, only low-density substances (including phytoplankton, zooplankton, organic detritus, algae fragments, and relatively light minerals) remain in the water column for long periods.

Higher WA-P contents in suspended solids indicate that the adsorption of inorganic phosphate and dissolved organic phosphorus onto suspended solids was higher than that of the surface sediments. Compared with surface sediments, suspended solid particles are smaller and their specific surface area increases when they enter the water body after being disturbed. Therefore, this increase in surface potential energy facilitates adsorption. This is consistent with the results of a simulation test, which demonstrated that the amount of adsorption and desorption of phosphate increased with decreased particle sizes. Previous studies [71] have shown that the content of inorganic phosphate and dissolved organic phosphorus in interstitial water was much higher than that in overlying water, which results in the diffusion and release of dissolved phosphorus from the interstitial water to the overlying water. According to a field investigation in Lake Arresø, a shallow lake in Denmark [72], the increase of nutrients released from dynamic suspension can reach up to 20-30 times the original value. This kind of release is likely aggravated by wave and wind disturbances, even though the content of dissolved phosphorus in the lake remains stable. Therefore, given that a large amount of released dissolved phosphorus can be re-adsorbed onto the suspended solids, the phosphorus content dissolved in the water likely remains relatively stable. This conclusion also supports the phosphate buffering mechanism proposed by Froelich [73]. In a few words, this rapid adsorption is beneficial to maintaining the balance of phosphorus in the water. Nevertheless, the suspended solids can also adsorb the dissolved phosphorus from the surface sediments, which is then released under certain conditions.

The NA- $P_{\mathrm{o}}$ content in suspended solids was significantly higher than that of the surface sediments, which may be due to the large amount of loose and amorphous inorganic macromolecular flocculate materials or organic detritus from surface sediment entering the water, increasing the organic phosphorus content in water. These substances not only have poor precipitation themselves, but also lead to poor precipitation of suspended solids after being adsorbed, which further leads to significant increases in the NA-P $P_{0}$ content of suspended solids.

According to the correlation analysis, the dissolved phosphorus content in the water of Lihu Lake is affected by both suspended solids and sediment. However, since high phosphorus contents are found in suspended solids, we should pay more attention to the suspended solids.

\section{Conclusions}

This study investigated the contents, spatial distribution, and sources of nitrogen and phosphorus forms in the suspended solids of Lihu Lake, and comparatively analyzed the different effects of suspended solids and surface sediments on water quality. After a comprehensive analysis and discussion of the results, our main conclusions were the following:

(1) The content of TN in the suspended solids of Lihu Lake was 758.9-3098.1 mg/kg and showed a decreasing trend from east to west. The proportions of various $\mathrm{N}$ forms in the suspended solids 
of the study areas were ranked as follows: Hydrolyzable nitrogen $(\mathrm{HN})>$ residual nitrogen $(\mathrm{RN})$ > exchangeable nitrogen (EN). The total phosphorus (TP) ranged from 294.8 to $1066.4 \mathrm{mg} / \mathrm{kg}$, the contents of IP and OP in suspended solids were 381.9 and $259.8 \mathrm{mg} / \mathrm{kg}$, respectively, and Ca-Pi and NA- $P_{0}$ were the major components of IP and OP. Almost all $P$ forms exhibited higher contents in the west than in the east. This is because several environmental dredging and ecological restoration projects have been carried out in western Lihu Lake.

(2) The correlation analysis of various forms of nitrogen and phosphorus in suspended solids indicated that there were different sources of suspended nitrogen for Lihu Lake, and TN in suspended solids was mainly affected by RN. Inorganic phosphorus in suspended solids likely originated from a common source, whereas organic phosphorus came from different sources. Phosphorus in suspended solids was controlled by both IP and OP, but was mainly affected by IP.

(3) The nitrogen in sediments was more bioavailable than that in suspended solids. In particular, once the physical and biochemical conditions of the sediment change, the EN in the sediment can be released and can diffuse into the overlying water, affecting the contents of $\mathrm{NH}_{4}{ }^{+}-\mathrm{N}$ and $\mathrm{TN}$ in water. The nitrogen forms in SS change continuously through rapid transformations when water quality conditions change. The contents of phosphorus in water were affected both by suspended solids and sediment. The bioavailable phosphorus content in suspended solids was higher than that in sediments, and the suspended solids influenced the $\rho$ (TP) by affecting particulate phosphorus. Suspended solids act as a medium that continually carries phosphorus from sediments to water and provides a substrate that enables phosphorus to remain in the water column for long periods.

Although many studies have been conducted on the nutrient concentrations in water and sediment, little is known about the nutrients in suspended solids. The spatial distribution characteristics of nitrogen and phosphorus forms in suspended solids were analyzed in this study. The impact on eutrophication was studied based on statistical analysis of these data. Future studies will hopefully be on the biogeochemical mechanisms, so as to provide theoretical support for controlling the eutrophication.

Author Contributions: Q.Z. provided the concept and designed the article content. J.L. performed the experiments and wrote the manuscript; Q.Z. verified the results and contributed to the proofreading of the manuscript. All authors have read and agreed to the published version of the manuscript.

Funding: This work was supported by the National Natural Science Foundation of China (No. U1803241, No. 51709238, and No. 51779230)

Acknowledgments: We thank Jiang's contribution to this article.

Conflicts of Interest: The authors declare no conflict of interest.

\section{Appendix A}

Table A1. The abbreviations and their meanings in this study.

\begin{tabular}{cc}
\hline Abbreviation & Meaning \\
\hline SS & suspended solids \\
TSS & total suspended solids \\
OM & organic matter \\
TN & total nitrogen \\
DTN & dissolved total nitrogen \\
PN & particulate nitrogen \\
TP & total phosphorus \\
DTP & dissolved total phosphorus \\
PP & particulate phosphorus \\
IP & inorganic phosphorus \\
OP & organic phosphorus \\
EN & exchangeable nitrogen \\
\hline
\end{tabular}


Table A1. Cont.

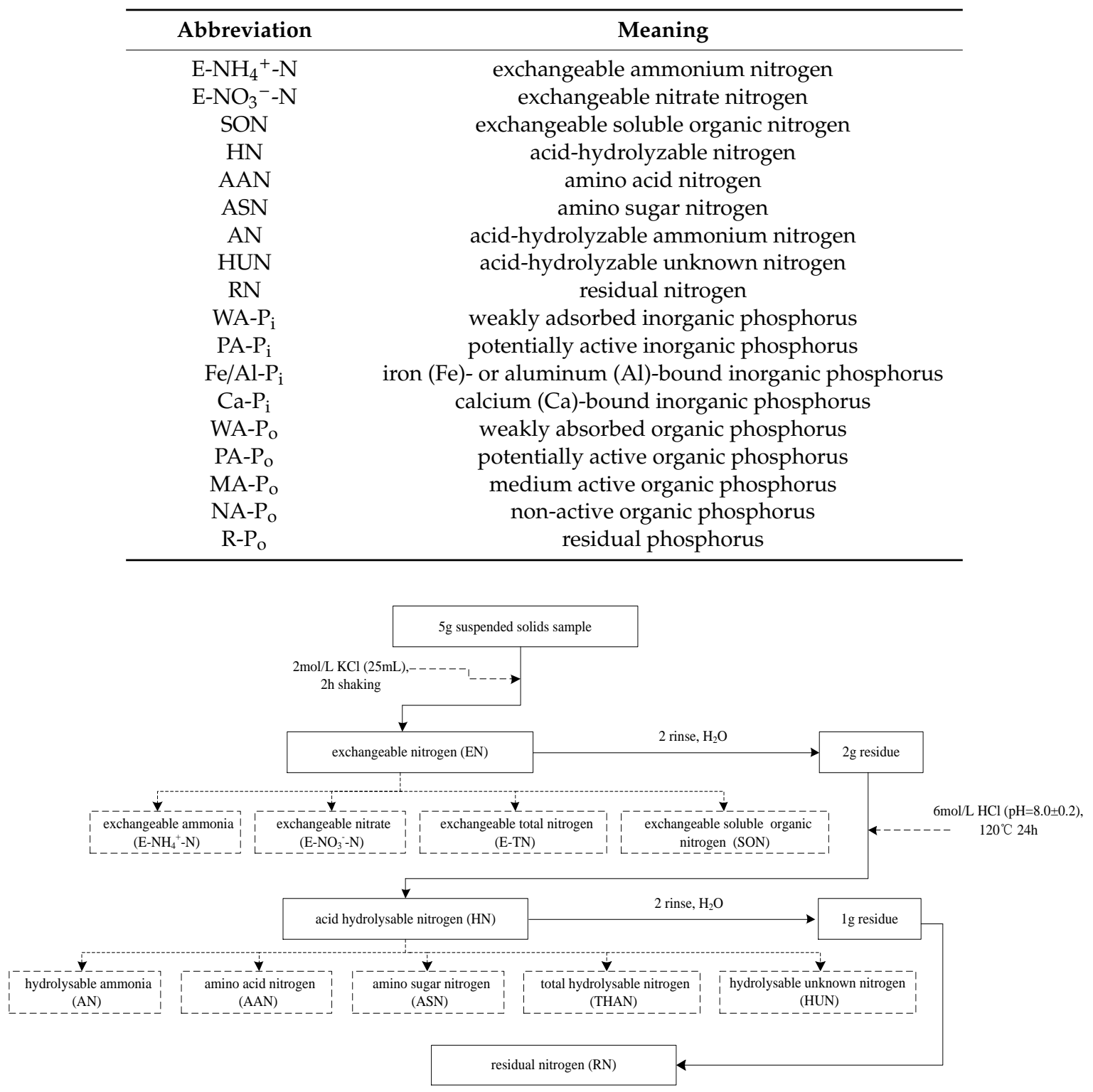

Figure A1. Measurement procedure for nitrogen fractionation in the suspended solids.

Table A2. Determination methods for nitrogen forms in suspended solids.

\begin{tabular}{lll}
\hline Index & Determination Method & Reference \\
\hline $\mathrm{EN}, \mathrm{HN}$ & $\begin{array}{l}\text { Alkaline potassium persulfate digestion } \\
\text { UV spectrophotometric method }\end{array}$ & $\begin{array}{l}\mathrm{HJ} \text { 636-2012 from Ministry of Ecology } \\
\text { and Environment, PRC }\end{array}$ \\
\hline $\begin{array}{l}\mathrm{E}-\mathrm{NH}_{4}{ }^{+}-\mathrm{N}, \\
\mathrm{AN}\end{array}$ & Nessler's reagent spectrophotometry & $\begin{array}{l}\text { HJ 535-2009 from Ministry of Ecology } \\
\text { and Environment, PRC }\end{array}$ \\
\hline $\mathrm{E}-\mathrm{NO}_{3}$ & Ultraviolet spectrophotometry & $\begin{array}{l}\mathrm{HJ} / \mathrm{T} \text { 346-2007 from Ministry of Ecology } \\
\text { and Environment, PRC }\end{array}$ \\
$\mathrm{NO}_{3}{ }^{-}-\mathrm{N}$ & $\mathrm{SON}=\mathrm{EN}-\mathrm{E}-\mathrm{NH}_{4}{ }^{+}-\mathrm{N}-\mathrm{E}-\mathrm{NO}_{3}{ }^{-}-\mathrm{N}$ & \\
$\mathrm{SON}$ & & $\begin{array}{l}\text { 1. Shao J.L.; Li Q.W.; Dong B.S., Liu H.S. } \\
\text { Determination of total free amino acid } \\
\text { in tea by Ninhydrin colorimetry. China }\end{array}$ \\
$\mathrm{AAN}$ & Ninhydrin colorimetric & Food Additives 2008, 02, 162-165.
\end{tabular}


Table A2. Cont.

\begin{tabular}{lll}
\hline Index & Determination Method & Reference \\
\hline ASN & Elson-Morgen colorimetric method & $\begin{array}{l}\text { Bremner J.M. Organic forms of nitrogen. } \\
\text { Madison: American Society of } \\
\text { Agronomy, 1965: 1148-1178. }\end{array}$ \\
\hline HUN & HUN = TH-AN-AAN-ASN & \\
RN, TN & Modified Kjeldahl method & $\begin{array}{l}\text { HJ 717 - 2014 from Ministry of Ecology } \\
\text { and Environment, PRC }\end{array}$ \\
\hline
\end{tabular}

Step 1:

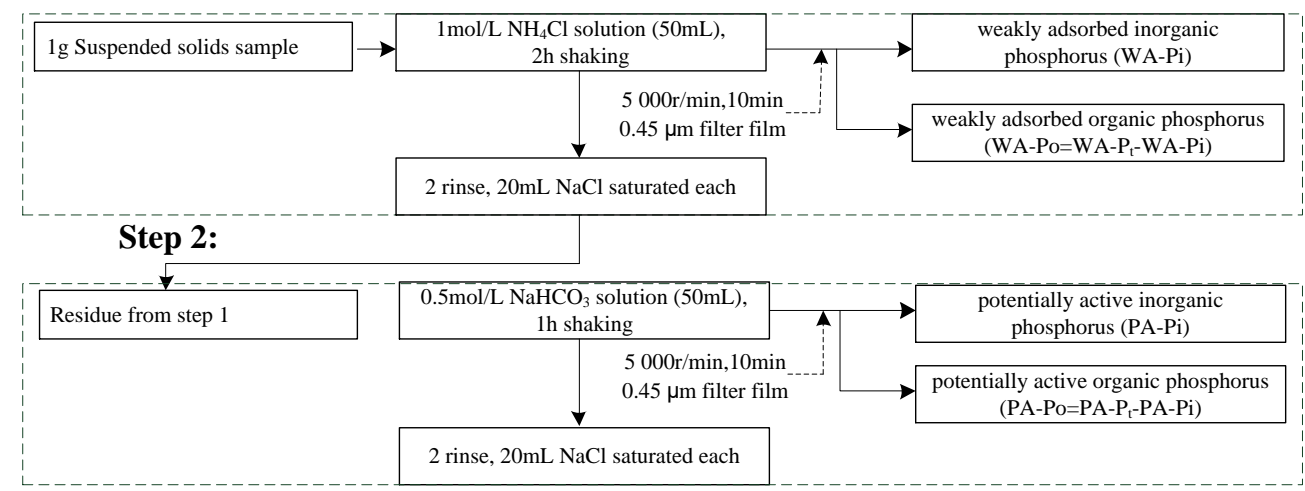

Step 3:

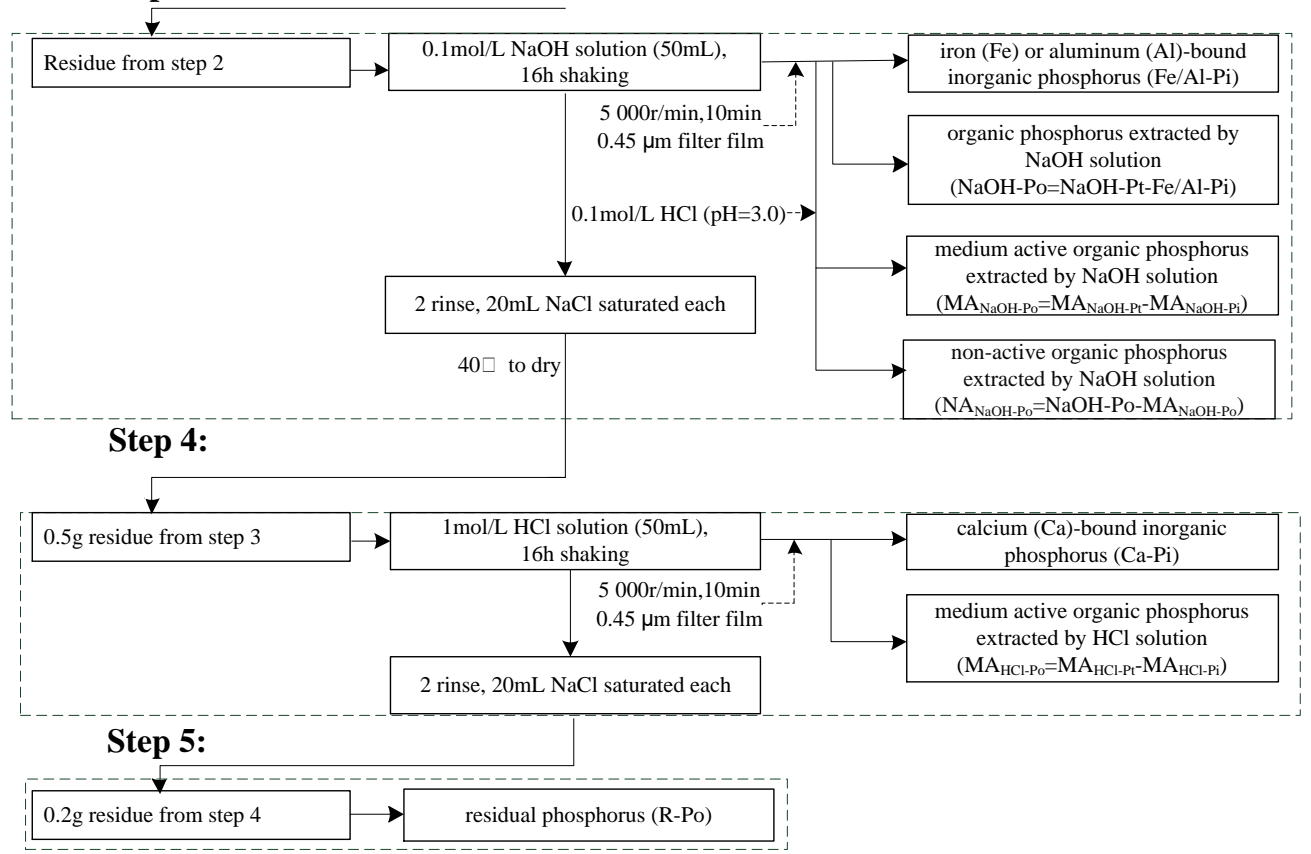

Figure A2. Measurement procedure for phosphorus fractionation in the suspended solids.

Table A3. Determination methods for phosphorus forms in suspended solids.

\begin{tabular}{lll}
\hline Index & Measurement & Reference \\
\hline \multirow{2}{*}{ inorganic phosphorus } & $\begin{array}{l}\text { phosphomolybdenum blue } \\
\text { spectrophotometric method }\end{array}$ & $\begin{array}{l}\text { HJ 593-2010 from Ministry of } \\
\text { Ecology and Environment, PRC }\end{array}$ \\
\hline \multirow{2}{*}{ TP } & $\begin{array}{l}\text { ammonium molybdate } \\
\text { spectrophotometric method }\end{array}$ & $\begin{array}{l}\text { GB 11893-89 from Ministry of } \\
\text { Ecology and Environment, PRC }\end{array}$ \\
\hline organic phosphorus & OP = TP - IP & \\
\hline
\end{tabular}



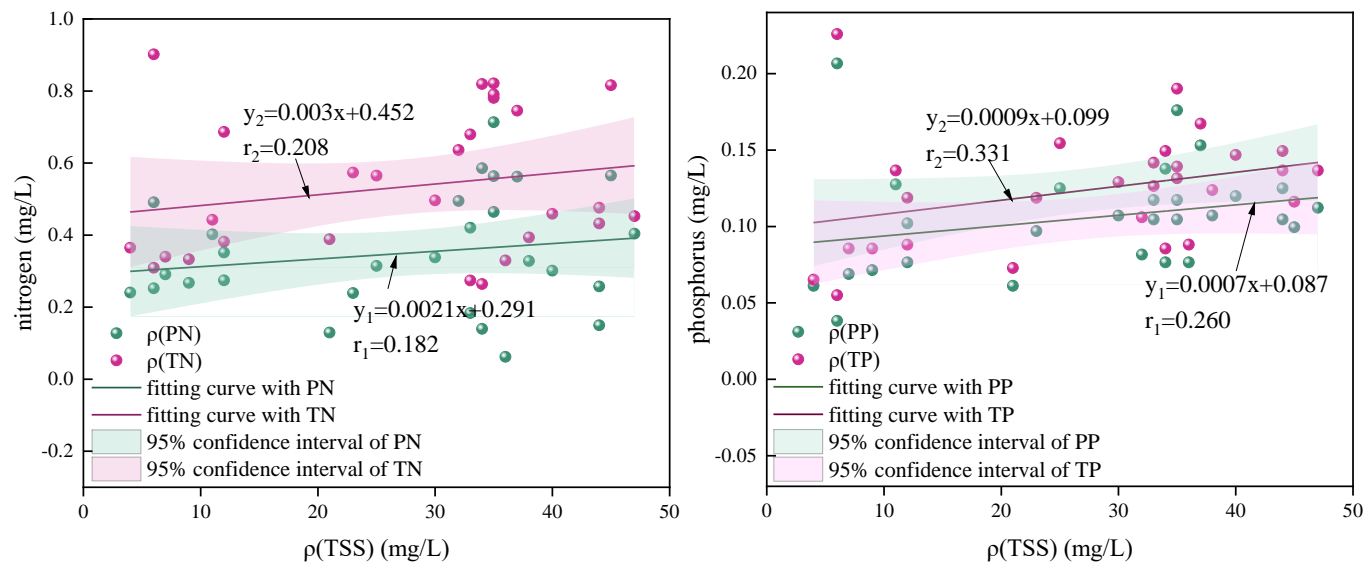

Figure A3. Relationship between annual mean total suspended solids (TSS), nitrogen, and phosphorus in the water of Lihu Lake.

Table A4. Basic information of water quality of Lihu Lake.

\begin{tabular}{cccccc}
\hline Index & Unit & Min & Max & Average & SD $^{\mathbf{1}}$ \\
\hline $\mathrm{T}$ & ${ }^{\circ} \mathrm{C}$ & 18.50 & 19.30 & 18.88 & 0.22 \\
$\mathrm{pH}$ & $/$ & 7.84 & 8.37 & 8.15 & 0.09 \\
$\mathrm{DO}$ & $\mathrm{mg} / \mathrm{L}$ & 3.60 & 8.50 & 7.05 & 0.96 \\
$\mathrm{ORP}$ & $\mathrm{mV}$ & 166.90 & 247.20 & 197.72 & 22.59 \\
$\mathrm{COD}$ & $\mathrm{mg} / \mathrm{L}$ & 3.42 & 8.06 & 4.41 & 0.82 \\
$\mathrm{Chl} . a$ & $\mathrm{mg} / \mathrm{m}^{3}$ & 6.30 & 50.54 & 16.20 & 11.11 \\
$\mathrm{TSS}$ & $\mathrm{mg} / \mathrm{L}$ & 4 & 47 & 27 & 13.69 \\
$\mathrm{TN}$ & $\mathrm{mg} / \mathrm{L}$ & 0.26 & 0.90 & 0.53 & 0.20 \\
$\mathrm{DTN}$ & $\mathrm{mg} / \mathrm{L}$ & 0.04 & 0.41 & 0.18 & 0.11 \\
$\mathrm{NH}_{4}{ }^{+}-\mathrm{N}$ & $\mathrm{mg} / \mathrm{L}$ & 0.03 & 0.25 & 0.11 & 0.05 \\
$\mathrm{NO}_{3}{ }^{-}-\mathrm{N}$ & $\mathrm{mg} / \mathrm{L}$ & 0.008 & 0.069 & 0.048 & 0.007 \\
$\mathrm{TP}$ & $\mathrm{mg} / \mathrm{L}$ & 0.05 & 0.23 & 0.12 & 0.04 \\
$\mathrm{DTP}$ & $\mathrm{mg} / \mathrm{L}$ & 0.004 & 0.114 & 0.032 & 0.031 \\
$\mathrm{IP}$ & $\mathrm{mg} / \mathrm{L}$ & 0.0006 & 0.0205 & 0.0087 & 0.006 \\
\hline
\end{tabular}

Table A5. General characteristics of nitrogen forms in surface sediments of Lihu Lake (content unit: $\mathrm{mg} / \mathrm{kg}$ ).

\begin{tabular}{ccccc}
\hline Index & Min & Max & Average & SD \\
\hline ETN & 33.42 & 431.19 & 144.50 & 95.27 \\
$\mathrm{E}-N H_{4}{ }^{-}-\mathrm{N}$ & 3.12 & 222.66 & 75.31 & 56.92 \\
${\mathrm{E}-N O_{3}{ }^{-}-\mathrm{N}}^{\mathrm{NON}}$ & 4.99 & 85.45 & 21.59 & 15.89 \\
$\mathrm{HN}$ & 17.76 & 126.22 & 47.60 & 30.42 \\
$\mathrm{AN}$ & 477.91 & 1156.33 & 701.96 & 158.99 \\
$\mathrm{AAN}$ & 208.28 & 698.38 & 335.19 & 108.17 \\
$\mathrm{ASN}$ & 10.10 & 383.07 & 162.91 & 94.27 \\
$\mathrm{HUN}$ & 3.49 & 29.17 & 11.79 & 5.81 \\
$\mathrm{RN}$ & 62.29 & 281.15 & 192.08 & 61.17 \\
$\mathrm{TN}$ & 0 & 1163.30 & 451.17 & 315.24 \\
\hline
\end{tabular}


Table A6. General characteristics of phosphorus forms in surface sediments of Lihu Lake (content unit: $\mathrm{mg} / \mathrm{kg}$ ).

\begin{tabular}{ccccc}
\hline Index & Min & Max & Average & SD \\
\hline WA-P & 1.40 & 20.50 & 6.37 & 4.50 \\
PA- $P_{i}$ & 10.34 & 107.15 & 53.85 & 24.84 \\
Fe/Al- $P_{i}$ & 40.93 & 243.13 & 106.93 & 51.85 \\
Ca- $P_{i}$ & 62.10 & 348.53 & 163.43 & 80.71 \\
WA-P & 0.67 & 10.69 & 3.01 & 1.92 \\
PA-P & 0.03 & 54.00 & 9.52 & 10.11 \\
MA-P $_{\mathrm{O}}$ & 50.97 & 142.15 & 91.29 & 18.85 \\
NA-P $_{\mathrm{o}}$ & 76.93 & 244.99 & 137.07 & 45.83 \\
\hline
\end{tabular}

\section{References}

1. Morgane, L.M.; Chantal, G.O.; Alain, M.; Yves, S. Eutrophication: A new wine in an old bottle? Sci. Total Environ. 2019, 651, 1-11.

2. Brigitte, V.L.; Celine, C. Modelling eutrophication in lake ecosystems: A review. Sci. Total Environ. 2019, 651, 2985-3001.

3. Bhagowati, B.; Ahamad, K.U. A review on lake eutrophication dynamics and recent developments in lake modelling. Ecohydrol. Hydrobil. 2016, 175, 1-12.

4. Schindler, D.W.; Carpenter, S.R.; Chapra, S.C.; Hecky, R.E.; Orihel, D.M. Reducing phosphorus to Curb Lake eutrophication is a success. Environ. Sci. Technol. 2016, 50, 8923-8929. [CrossRef] [PubMed]

5. McCrakin, M.; Jones, H.P.; Jones, P.C.; Mateos, D.M. Recovery of lakes and coastal marine ecosystems from eutrophication: A global meta-analysis. Limnol. Oceanogr. 2017, 62, 57-518. [CrossRef]

6. Cook, S.C.; Housley, L.; Back, J.A.; King, R.S. Freshwater eutrophication drives sharp reductions in temporal beta diversity. Ecology 2018, 99, 47-56. [CrossRef]

7. O'Hare, M.T.; Pedersen, A.B.; Baumgarte, I.; Freeman, A.; Gunn, I.D.M. Responses of aquatic plants to eutrophication in rivers: A revised conceptual model. Front. Plant. Sci. 2018, 9, 1-13. [CrossRef]

8. Glibert, P.M. Harmful algae at the complex nexus of eutrophication and climate change. Harmful Algae 2019, in press. [CrossRef]

9. Zeng, J.; Yang, L.Y.; Xiao, L. Biogeochemical cycling of nitrogen in lakes and the role of microorganisms in conversion of nitrogen compounds. J. Lake Sci. 2007, 19, 382-389.

10. Schindler, D.W.; Hecky, R.E.; Findla, Y. Eutrophication of lakes cannot be controlled by reducing nitrogen input: Results of a 37 year whole ecosystem experiment. PNAS 2008, 105, 11254-11258. [CrossRef]

11. Yu, J.H.; Fan, C.X.; Zhong, J.C.; Zhang, Y.L. Evaluation of in situ simulated dredging to reduce internal nitrogen flux across the sediment-water interface in Lake Taihu, China. J. Environ. Pollut. 2016, 214, 866-877. [CrossRef] [PubMed]

12. Zhu, Y.Y.; Jin, X.; Tang, W.Z.; Meng, X.; Shan, B.Q. Comprehensive analysis of nitrogen distributions and ammonia nitrogen release fluxes in the sediments of Baiyangdian Lake, China. J. Environ. Sci. 2019, 76, 319-328. [CrossRef] [PubMed]

13. Cao, X.; Wang, Y.Q.; He, J.; Luo, X.Z.; Zheng, Z. Phosphorus mobility among sediments, water and cyanobacteria enhanced by cyanobacteria blooms in eutrophic Lake Dianchi. Environ. Pollut. 2016, 17, 1-8. [CrossRef] [PubMed]

14. Zhou, R.; Yuan, X.Y.; Marip, J.B.; Yu, H.H.; Zhang, Q.; Tang, D.D. Spatial distributions of transferable nitrogen forms and influencing factors in sediments from inflow rivers in different lake basins. Environ. Sci. 2018, 39, 1122-1128.

15. Cavalcante, H.; Araújo, F.; Noyma, N.P.; Becker, V. Phosphorus fraction in sediments of tropical semiarid reservoirs. Sci. Total Environ. 2018, 619-620, 1022-1029. [CrossRef]

16. Brezonik, P.; Bouchard, W.B., Jr.; Finlay, J.C.; Griffin, C.G.; Olmanson, L.G.; Anderson, J.P. Color, chlorophyll a, and suspended solids effects on Secchi depth in lakes: Implications for trophic state assessment. Ecol. Appl. 2019, 29, e01871. [CrossRef] 
17. Zhang, C.; Zhang, W.N.; Huang, Y.X.; Gao, X.P. Analysing the correlations of long-term seasonal water quality parameters, suspended solids and total dissolved solids in a shallow reservoir with meteorological factors. Environ. Sci. Pollut. Res. 2017, 24, 6746-6756. [CrossRef]

18. Nasrabadi, T.; Ruegner, H.; Sirdari, Z.Z.; Schiwientek, M.; Grathwohl, P. Using total suspended solids (TSS) and turbidity as proxies for evaluation of metal transport in river water. Appl. Geochem. 2016, 68, 1-9. [CrossRef]

19. Sandström, S.; Futter, M.N.; Kyllmar, K.; Bishop, K.; O'Connell, D.W.; Djodjic, F. Particulate phosphorus and suspended solids losses from small agricultural catchments: Links to stream and catchment characteristics. Sci. Total Environ. 2020, 711, 1-12. [CrossRef]

20. Arantes, R.; Schveitzer, R.; Magnotti, C.; Lapa, K.R.; Vinatea, L. A comparison between water exchange and settling tank as a method for suspended solids management in intensive biofloc technology systems: Effects on shrimp (Litopenaeus vannamei) performance, water quality and water use. Aquac. Res. 2017, 48, 1478-1490. [CrossRef]

21. Qi, C.; Wang, G.X.; Wu, X.T.; Xu, X.G.; Han, R.M.; Wu, S.J. Deposition Characteristics of Suspended Solids and the Response of Dissolved Nutrients in spring in the Western Lakeside of Taihu Lake. Environ. Sci. 2017, 38, 95-103.

22. Niu, Y.; Jiang, X.; Wang, K.; Xia, J.D.; Jiao, W.; Niu, Y.; Yu, H. Meta analysis of heavy metal pollution and sources in surface sediments of Lake Taihu, China. Sci. Total Environ. 2020, 700, 134509. [CrossRef]

23. Ti, C.P.; Gao, B.; Luo, Y.X.; Wang, S.W.; Chang, S.X.; Yan, X.Y. Dry deposition of $\mathrm{N}$ has a major impact on surface water quality in the Taihu Lake region in southeast China. Atmos. Environ. 2018, 190, 1-9. [CrossRef]

24. Wang, S.H.; Wang, W.W.; Jiang, X. Spatial-temporal dynamic changes of nitrogen and phosphorus and different analysis in water body of Lihu Lake. China Environ. Sci. 2014, 34, 1268-1276.

25. Wang, W.W.; Wang, S.H.; Jiang, X.; Zheng, B.H. Occurrence characteristics and release potential of nitrogen fractions in sediments of Lihu Lake. China Environ. Sci. 2017, 37, 292-301.

26. Wang, S.H.; Zhao, L.; Jiang, X. Forms, occurrence characteristics and biological of phosphorus in surface sediments of Lihu Lake. Res. Environ. Sci. 2015, 28, 1741-1748.

27. Gu, G.; Lu, G.F. On the integrated control of water environment of Wuli Lake, Lake Taihu. J. Lake Sci. 2004, $16,56-60$.

28. Li, W.C. Biological and environmental succession in Wuli Bay of Taihu Lake. J. Lake Sci. 1996, 8, 37-45.

29. Morris, D.P.; Zagarese, H.; Williamson, C.E.; Balseiro, E.G.; Hargreaves, B.R. The attenuation of solar UV radiation in lakes and the role of dissolved organic carbon. Limmol. Oceanogr. 1995, 40, 1381-1391. [CrossRef]

30. Nõges, P.; Nõges, T.; Tuvikene, L.; Smal, H.; Ligeza, S.; Kornijów, R. Factors controlling hydrochemical and trophic state variables in 86 shallow lakes in Europe. Hydrobiologia 2003, 506-509, 51-58. [CrossRef]

31. Jeppsen, E.; Jensen, J.P.; Sødergaard, M.; Hansen, K.S. Does resuspension prevent a shift to a clear state in shallow lakes during reoligotrophication? Limmol. Oceanogr. 2003, 48, 1913-1919. [CrossRef]

32. Zhang, Y.L.; Qin, B.Q.; Zhu, G.W.; Huang, Q.F.; Gu, X.H. The light condition and affect factors in Hangzhou West Lake. Resour. Environ. Yangtze Basin 2005, 14, 744-749.

33. Zhang, Y.L.; Qin, B.Q.; Chen, W.M.; Luo, L.C. A study on total suspended matter in Lake Taihu. Resour. Environ. Yangtze Basin 2004, 13, 266-271.

34. Liu, Z.H.; Li, Y.M.; Tan, J.; Guo, Y.L.; Zhou, L.; Liu, G. Construction of semi-analytical model for inversing total suspended matter in Lake Taihu and Chaohu and assessment of its applicability. Environ. Sci. 2012, 33, 3000-3008.

35. Lange, G.J. Distribution of exchangeable, fixed, organic and total nitrogen in interbedded turbiditic pelagic sediments of the Maderia abyssal-plain, eastern north-Atlantic. Mar. Geol. 1992, 109, 95-114. [CrossRef]

36. Wang, S.R.; Jiao, L.X.; Jin, X.C. Distribution of total, exchangeable and fixed nitrogen in the sediments from shallow lakes in the middle and lower reaches of the Yangtze River. Acta Sci. Circumstantiae 2008, 28, 37-43.

37. Jin, J.; Yuan, X.Y.; Chen, S.W.; Li, Z.Y.; Ye, H.M.; Xu, H.Y. Distribution of nitrogen forms in suspended sediments and surface sediments of East Tiaoxi River, upper reaches of Taihu Basin and their influence factors. J. Lake Sci. 2017, 29, 594-603.

38. Zehr, J.P.; Paulsen, S.G.; Axler, R.P. Dynamics of dissolved organic nitrogen in subalpine Castle Lake, California. Hydrobiologia 1988, 157, 33-45. [CrossRef]

39. Bremner, J.M. Organic Forms of Soil Nitrogen; Bremner, J.M., Black, C.A., Eds.; Methods of soil analysis; American Society of Agronomy: Madison, WI, USA, 1965; pp. 1148-1178. 
40. Mengel, K.; Schmeer, H. Effect of straw, cellulose and lignin on the turnover and availability of labelled ammonium nitrate. Biol. Fertil. Soils 1985, 1, 175-181. [CrossRef]

41. Wang, S.R.; Jiao, L.X.; Jin, X.C. Characteristics of organic nitrogen fractions in sediments of shallow lakes in the middle and lower reaches of the Yangtze River area in the China. Water Environ. J. 2012, 26, 473-481. [CrossRef]

42. Zhong, L.X.; Wang, S.H.; Jiang, X.; Jin, X.C. Speciation characteristics of different combined nitrogen in the spring sediments of Chaohu Lake by sequential extraction methods. J. Agro-Environ. Sci. 2009, 28, 2132-2137.

43. Stevenson, F.J. Humus Chemistry: Genesis, Composition, Reactions; John Wiley\&Sons: New York, NY, USA, 1994; pp. 55-119.

44. Schulten, H.R.; Schnitzer, M. The chemistry of soil organic nitrogen: A review. Biol. Fertil. Soils 1997, 26, 1-15. [CrossRef]

45. Jones, D.L.; Shannon, D.; Junvee-Fortune, T.; Farrar, J.F. Plant capture of free amino acids is maximized under high soil amino acid concentrations. Soil Biol. Biochem. 2005, 37, 179-181. [CrossRef]

46. Ruban, V.; Brigault, S.; Demare, D.; Phillippe, A.M. An investigation of the origin and mobility of phosphorus in freshwater sediments from Bort-Les-Orgues Reservoir, France. J. Environ. Monit. 1999, 1, 403-407. [CrossRef]

47. Sun, S.J.; Huang, S.L.; Sun, X.M.; Wen, W. Phosphorus fractions and its release in the sediments of Haihe River, China. J. Environ. Sci. 2009, 21, 291-295. [CrossRef]

48. Fabre, A.; Qotbi, A.; Dauta, A.; Baldy, V. Relation between algal available phosphate in the sediments of the River Garonne and chemically-determined phosphate fractions. Hydrobiologia 1996, 335, 43-48. [CrossRef]

49. William, J.D.H.; Shear, H.; Thomas, R.L. Availability to Scenedesmus, quadrcauda of different forms of phosphorus in sedimentary materials from the Great Lakes. Limnol. Oceanogr. 1980, 25, 1-11. [CrossRef]

50. Kaiserli, A.; Voutsa, D.; Samara, C. Phosphorus fractionation in lake sediments-Lakes Volvi and Koronia, N. Greece. Chemosphere 2002, 46, 1147-1155. [CrossRef]

51. He, Z.Q.; Griffin, T.S.; Honeycutt, C.W. Evaluation of soil phosphorus transformations by sequential fraction and phosphatase hydrolysis. Soil Sci. 2004, 169, 515-527. [CrossRef]

52. Liu, Q.; Liu, S.L.; Zhao, H.D.; Deng, L.; Wang, C. The phosphorus speciation in the sediments up and down-stream of cascade dams along the middle Lancang River. Chemosphere 2015, 120, 653-659. [CrossRef]

53. Zhang, R.Y.; Wu, F.C.; Liu, C.Q.; Fu, P.Q.; Li, W. Characteristics of organic phosphorus fractions in different trophic sediments of lakes from the middle and lower reaches of Yangtze River region and Southwestern Plateau, China. Environ. Pollut. 2008, 152, 366-372. [CrossRef]

54. Sun, J.; Wang, S.R.; Zeng, Q.R. Distribution characteristics of organic phosphorus fractions and influencing factors in surface sediments of Lake Erhai. Res. J. Environ. Sci. 2011, 24, 1226-1232.

55. Ivanoff, D.B.; Reddy, K.R.; Robinson, S. Chemical fractionation of organic phosphorus in selected histosols. Soil Sci. 1998, 163, 36-45. [CrossRef]

56. Chen, H.L.; Yuan, X.Y.; Wang, H.; Li, Z.Y.; Xu, H.Y. Distributions of phosphorus fractions in suspended sediments and surface sediments of Tiaoxi mainstreams and cause analysis. Environ. Sci. 2015, 36, 464-470.

57. Huang, J.C.; Gao, J.F.; Jiang, Y. Source, distribution and export coefficient of phosphorus in lowland polders of Lake Taihu Basin, China. Environ. Pollut. 2017, 231, 1274-1283. [CrossRef]

58. He, Z.Q.; Senwo, Z.N.; Mankolo, R.N.; Honeycutt, C.W. Phosphorus fractions in poultry litter characterized by sequential fractionation coupled with phosphatase hydrolysis. J. Food Agric. Environ. 2006, 4, 304-312.

59. Huang, W.L.; Cai, W.; Huang, H.; Lei, Z.F.; Zhang, Z.Y.; Tay, J.H.; Lee, D.J. Identification of inorganic and organic species of phosphorus and its bio-availability in nitrifying aerobic granular sludge. Water Res. 2015, 68, 423-431. [CrossRef]

60. Xu, D.; Ding, S.M.; Li, B.; Bai, X.L.; Fan, C.X.; Zhang, C.S. Speciation of organic phosphorus in a sediment profile of Lake Taihu: I chemical forms and their transformation. J. Environ. Sci. 2013, 25, 637-644. [CrossRef]

61. Zan, F.Y.; Huo, A.L.; Xi, B.D.; Li, Q.Q.; Liao, H.Q.; Zhang, J.T. Phosphorus distribution in the sediments of a shallow eutrophic lake, Lake Chaohu, China. Environ. Earth Sci. 2011, 62, 1643-1653. [CrossRef]

62. Yu, H.; Zhang, L.L.; Yan, S.W.; Li, H.L.; Xu, J. Atmospheric wet deposition characteristics of nitrogen and phosphorus nutrients in Taihu Lake and contributions to the lake. Res. Environ. Sci. 2011, 24, 1210-1219.

63. Liu, T.; Yang, L.Y.; Hu, Z.X.; Sun, Y.N. Spatial-temporal features of atmospheric deposition of nitrogen and phosphorus to the Lake Taihu. ATEM 2012, 24, 20-22. 
64. Wang, Q.L.; Liang, T. Distribution patterns and dynamics of phosphorus forms in the overlying water and sediment of Dongting Lake. J. Great Lake Res. 2016, 42, 565-570. [CrossRef]

65. Monchamp, M.E.; Pick, F.R.; Beisner, B.E.; Maranger, R. Nitrogen forms influence microcystin concentration and composition via changes in cyanobacterial community structure. PLoS ONE 2014, 9, 1-10. [CrossRef]

66. Horst, G.P.; Sarnelle, O.; White, J.D.; Hamilton, S.K.; Kaul, R.B.; Bressie, J.D. Nitrogen availability increases the toxin quota of a harmful cyanobacterium, Microcystic aeruginosa. Water Res. 2014, 54, 188-198. [CrossRef] [PubMed]

67. Li, R.; Tang, C.Y.; Li, X.; Jiang, T.; Shi, Y.P.; Cao, Y.J. Reconstructing the historical pollution levels and ecological risks over the past sixty years in sediments of the Beijiang River, South China. Sci. Total Environ. 2019, 649, 448-460. [CrossRef] [PubMed]

68. Lindström, M.; Håkanson, L.; Abrahamsson, O.; Johansson, H. An empirical model for prediction of lake water suspended particulate matter. Ecol. Model. 1999, 121, 185-198. [CrossRef]

69. Liu, X.J.; Li, Z.B.; Li, P.; Zhu, B.B.; Long, F.F.; Cheng, Y.T. Changes in carbon and nitrogen with particle size in bottom sediments in the Dan River, China. Quatern. Int. 2015, 380-381, 305-313. [CrossRef]

70. Sulce, S.; Lopez, D.P.; Jacquin, F.; Vong, P.C.; Guiraud, G. Study of immobilization and remobilization of nitrogen fertilizer in cultivated soils by hydrolytic fractionation. Eur. J. Soil Sci. 1996, 47, 249-255. [CrossRef]

71. Löfgren, S.; Boström, B. Interstitial water concentrations of phosphorus, iron and manganese in a shallow, eutrophic Swedish lake-Implications for phosphorus cycling. Wat. Res. 1989, 23, 1115-1125. [CrossRef]

72. Sødergaard, M.; Kristensen, P.; Jeppesen, E. Phosphorus release from resuspended sediment in the shallow and wind-exposed Lake Arresø, Denmark. Hydrobiologia 1992, 228, 91-99.

73. Froelich, P.N.; Bender, M.L.; Heath, G.R. Phosphorus accumulation rates in metalliferous sediments on the east pacific rise. Earth Planet. Sci. Lett. 1977, 34, 351-359. [CrossRef]

(C) 2020 by the authors. Licensee MDPI, Basel, Switzerland. This article is an open access article distributed under the terms and conditions of the Creative Commons Attribution (CC BY) license (http://creativecommons.org/licenses/by/4.0/). 